Article

\title{
Spatial Dynamics of Invasive Para Grass on a Monsoonal Floodplain, Kakadu National Park, Northern Australia
}

\author{
James Boyden 1,*(D), Penelope Wurm ${ }^{1} \mathbb{D}$, Karen E. Joyce ${ }^{2} \mathbb{D}$ and Guy Boggs ${ }^{1,3}$ \\ 1 Research Institute for Environment and Livelihoods, Charles Darwin University, Darwin, \\ Northern Territory 0909, Australia \\ 2 James Cook University, College of Science and Engineering, Cairns, Queensland 4879, Australia \\ 3 The Western Australian Biodiversity Science Institute, 133 St. Georges Tce., Perth, WE 6000, Australia \\ * Correspondence: Jamesdwn@internode.on.net
}

Received: 11 July 2019; Accepted: 29 August 2019; Published: 6 September 2019

\begin{abstract}
African para grass (Urochloa mutica) is an invasive weed that has become prevalent across many important freshwater wetlands of the world. In northern Australia, including the World Heritage landscape of Kakadu National Park (KNP), its dense cover can displace ecologically, genetically and culturally significant species, such as the Australian native rice (Oryza spp.). In regions under management for biodiversity conservation para grass is often beyond eradication. However, its targeted control is also necessary to manage and preserve site-specific wetland values. This requires an understanding of para grass spread-patterns and its potential impacts on valuable native vegetation. We apply a multi-scale approach to examine the spatial dynamics and impact of para grass cover across a $181 \mathrm{~km}^{2}$ floodplain of KNP. First, we measure the overall displacement of different native vegetation communities across the floodplain from 1986 to 2006. Using high spatial resolution satellite imagery in conjunction with historical aerial-photo mapping, we then measure finer-scale, inter-annual, changes between successive dry seasons from 1990 to 2010 (for a $48 \mathrm{~km}^{2}$ focus area); Para grass presence-absence maps from satellite imagery (2002 to 2010) were produced with an object-based machine-learning approach (stochastic gradient boosting). Changes, over time, in mapped para grass areas were then related to maps of depth-habitat and inter-annual fire histories. Para grass invasion and establishment patterns varied greatly in time and space. Wild rice communities were the most frequently invaded, but the establishment and persistence of para grass fluctuated greatly between years, even within previously invaded communities. However, these different patterns were also shown to vary with different depth-habitat and recent fire history. These dynamics have not been previously documented and this understanding presents opportunities for intensive para grass management in areas of high conservation value, such as those occupied by wild rice.
\end{abstract}

Keywords: Vegetation mapping; landscape ecology; Invasive weeds; freshwater wetlands; adaptive land management; biodiversity conservation; fire; remote sensing

\section{Introduction}

Wetlands are one of the world's most threatened ecosystems. Over 50\% of wetlands in the north America, Europe, Australia and New Zealand were destroyed during the twentieth century and others elsewhere degraded [1]. Some authors estimate the greatest global loss of wetlands has been in Asia [2]. Exotic weed invasions are assessed to be one of the main drivers of ongoing degradation of wetlands, globally $[1,3,4]$. The current causes of wetland degradation and loss (human land uses, invasive species, water extraction and pollution) are expected to be exacerbated by concomitant impacts of climate change (i.e., changed temperature and rainfall regimes; risk of inundation from sea-level rise) [5]. 
Tropical grasses such as African para grass (Urochloa mutica) have become globally prevalent since introductions for pasture to various continents [6]. Such grasses tend to become invasive and can disrupt ecological dynamics by altering hydrological flows, nutrient cycles and seedbed conditions [7-9]. These high-biomass grasses are also likely to increase the frequency and severity of wildfires [10-14] and threaten valued endemic flora and fauna $[3,15,16]$.

Para grass has already established in tropical wetlands across northern Australia [16,17]. Within Kakadu National Park (KNP), which includes internationally significant World Heritage and RAMSAR-listed freshwater wetlands [18], para grass is beyond eradication and continues to increase in extent [19-21]. It can form large, dense, patches that displace native vegetation of high conservation value, such as areas previously dominated by native rice (Oryza meridionalis and O. rufipogon), and the annual native water chestnut (Eleocharis dulcis) $[8,14,16,19,22,23]$. These rice populations of northern Australia comprise a globally significant genetic resource for cultivated rice breeding $[24,25]$. Native rice and water chestnut also underpin the floodplain vertebrate food web, which includes the iconic and range-restricted magpie goose [26,27] and dusky plains rat $[28,29]$ both of which feed directly on native rice. If unmanaged, para grass could also adversely affect regionally important economic opportunities such as tourism and wild harvest of plant products that are culturally significant to Indigenous people [30,31].

Wetland conservation managers are called upon to make efficacious, spatially explicit, decisions to prioritize and deploy the limited available resources to control weeds. This requires a monitoring program that provides knowledge of: (A) The historical context and dynamics of weed establishment across landscapes [32,33]; (B) the spatial dynamics and impact of invasions, over time and in relation to the distributions of differently valued endemic life under conservation [34] and (C) the environmental factors influencing these dynamics [35-37]. Since the dynamic processes that induce vegetation change operate over multiple scales, it is also imperative that vegetation be monitored over an appropriate range of spatial and temporal scales and in different landscape contexts [38].

Without such a vegetation monitoring framework it is very difficult to assess the success (or otherwise) of specific weed control programs [37,39]. Lack of timely information on the dynamics and spatial distribution of weeds hampers control operations by creating uncertainty in decision-making [40-42]. However, gathering information on vegetation distribution in wetland environments has tended to be opportunistic, fragmented and inconsistent in time and space [40,43]. In northern Australia, monitoring efforts have also been limited by high costs and the many logistic challenges associated with accurately surveying these expansive, remote and relatively inaccessible monsoonal floodplains [40,44].

On floodplains of KNP, the seasonal dynamics of vegetation cover are largely controlled by the highly variable rains of the tropical monsoon. Their magnitude and duration directly influence the conditions that affect plant growth, such as nutrient cycling, water depths and the frequency and duration of wet or dry periods (i.e., when floodplain soils are either inundated by water or exposed to air) [12,45-49]. They also influence regimes of disturbance such as the incidence, extent and intensity of dry-season fire, which have a profound effect on vegetation dynamics [50]. These variables interact together with the low-relief topography of these plains to form vegetation patterns.

Prioritization of weed control and research activities requires an understanding of which floodplain habitats and endemic vegetation are most prone to invasion or more severe impact, over time. In this context, distribution patterns of different native vegetation and para grass are known to correlate strongly with floodplain inundation frequency and depth [12,51,52]. Further knowledge on the spatial dynamics of vegetation patterns in relation to these variables, may assist in more effective prioritization of para grass control activities and in the identification of timely, site-specific, opportunities for implementing para grass control. For example, an understanding of weed invasion rates across different water-depth habitats could guide where and when control activities are directed.

In addition, the persistence of dense para grass cover may vary between these different habitats. Quantifying these differences could provide important information on the potential impacts of para 
grass, in terms of the permanency of displacement of native vegetation in any one location. In this regard, fire can have various effects on vegetation dynamics, because fire regimes (e.g., frequency and intensity) and environmental conditions immediately before and after fire will vary across different habitats on the floodplain. The periodic removal of dense perennial grass cover (e.g., para grass) by fire can favor conditions for the re-establishment of more favored plant species, such as native rice $[30,53,54]$. Alternatively and under different conditions, fire may favor the continued invasion of para grass into new areas [55]. Quantifying these effects is important for modeling invasion risk, as well as identifying site- and time-specific opportunities for the remediation of native vegetation.

Optical remote sensing (RS) can provide the quantitative, multi-scale information necessary to assess vegetation condition and the risk and impact of weed invasions across landscapes [20,43,51,56-60]. It can provide accurate, cost-effective, continuous and contiguous spatial information on the distribution of vegetation and habitats over extensive and often inaccessible wetland landscapes [40,61-70]. Indeed, RS is often the only source of information readily available to characterise habitats, and monitor and detect weeds or environmental change in such areas [71,72]. Measurements can also be repeated with relative consistency over time, obtained at range of scales and spatially integrated within geographic information systems [73-76]. However, inherent and sometimes avoidable measurement errors contribute to uncertainty in RS interpretation, which therefore must be validated by finer-scale ground surveys, nested within the landscape. It is also important to develop RS image classification methods that deliver consistent and accurate spatial and temporal of information. This is also important because errors accumulate or are even propagated in vegetation change analyses [77-79].

In this study, we apply RS to monitor and understand the spatial dynamics of the environmental weed, para grass (Urochloa mutica) on a freshwater floodplain of KNP, Northern Territory, Australia. Our aim was to quantify the spatial dynamics of para grass invasion and establishment in relation to native vegetation, water depth and fire history on this floodplain. These analyses are conducted in a GIS environment using a range of monitoring products derived by remote sensing in combination with a field survey. In so doing, we assess the impacts and risk of para grass invasion on native vegetation communities and floodplain habitats, typical of freshwater wetlands in the region. This research provides valuable information for planning and prioritisation of site-specific management programs for this weed on this floodplain and other monsoonal wetlands under conservation management.

\section{Materials and Methods}

\subsection{Site and Data Descriptions}

The Magela Creek floodplain is located in the monsoonal tropics of KNP and the Alligator Rivers Region of northern Australia (Figure 1). The first confirmed reports of para grass on this floodplain are from the 1950s [80,81]. A few planting trials for para grass as pasture occurred in small areas up until 1969 [21,80]. No active control of para grass has occurred on the floodplain since its incorporation into the KNP conservation zone in 1981. In fact, perennial grasses (including para grass) began to proliferate on KNP floodplains in the late 1980s after intense grazing pressure was relaxed by the controlled removal of feral water buffalo from the Park [82]. This situation makes this site suitable for studying the dynamics of para grass under inherent conditions, without weed control intervention [51]. 


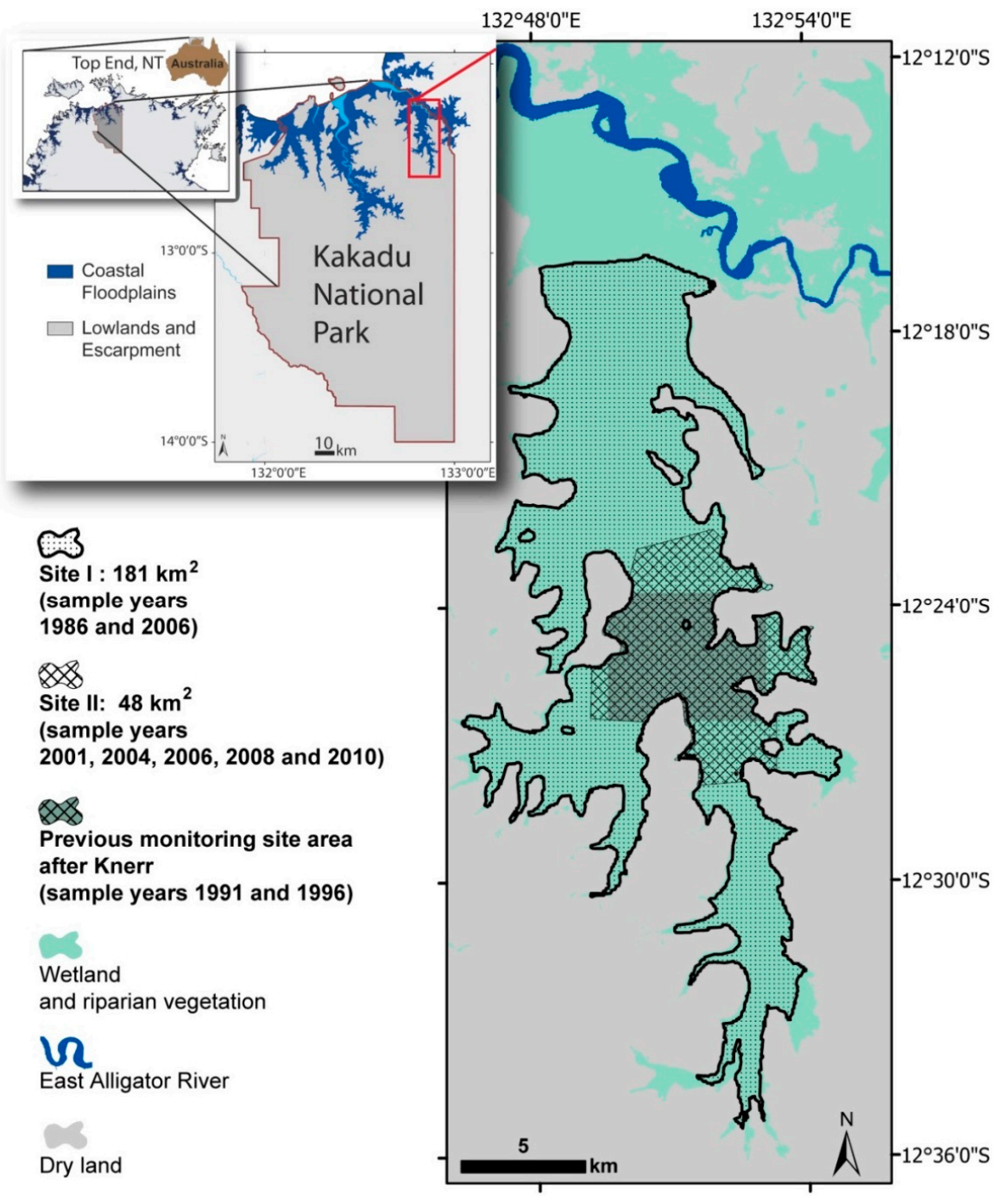

Figure 1. Para grass monitoring sites on the Magela Creek floodplain within Kakadu National Park, NT, Australia, showing: Site I.; the greater floodplain area $\left(181 \mathrm{~km}^{2}\right)$ for measuring native vegetation types displaced by para grass between 1986 to 2006; and Site II $\left(48 \mathrm{~km}^{2}\right)$ which encloses the largest para grass infestation, where finer-scale dynamics of change were measured from 2001-2010. Site II contained para grass areas which were mapped historically for this infestation [19], and now combined in some Site II analyses.

The datasets used in this study are summarized in Table 1. First, the displacement of different native vegetation communities by dense para grass cover is estimated for the whole floodplain area from maps representing vegetation cover in 1986 and 2006 (Site I.; Figure 1). Then, inter-annual changes in para grass cover were measured for the $48 \mathrm{~km}^{2}$ focus area (Site II, Figure 1). In these analyses, we mapped para grass cover from high spatial resolution satellite images captured biennially from 2001 to 2010 (Table 3). Details on the production and accuracy assessment of these maps are provided in Section 2.3.1. The mapped changes in para grass cover were then interrelated to published maps of floodplain depth habitat and fire history [51]. Historical maps of para grass cover were also available within the Site II area for years 1991 and 1996 [19]. These maps were included in analyses to assess rates of change over time (Section 2.3). 
Table 1. Map datasets used to characterize the spatial distribution of para grass and native vegetation in context to environmental variables, water depth and fire history.

\begin{tabular}{|c|c|c|c|c|}
\hline Site Analyses & Map Variable & Mapping Year(s) & Description & Estimated Scale/Accuracy \\
\hline \multirow{2}{*}{$\begin{array}{l}\text { Broad scale, generalized, } \\
\text { analyses } \\
\text { (Site I) }\end{array}$} & Para grass cover & 2006 & $\begin{array}{l}\text { Published vegetation map produced by object-based image } \\
\text { analysis from } 2006 \text { Landsat multi-temporal (dry season) } \\
\text { composite using the Nearest Neighbour classifier [20]. }\end{array}$ & $\begin{array}{l}\text { Horizontal accuracy } \pm 30 \mathrm{~m} \text {. } \\
\text { Overall accuracy for para grass cover class }=96 \%\end{array}$ \\
\hline & $\begin{array}{l}\text { Native vegetation } \\
\text { cover }\end{array}$ & 1986 & $\begin{array}{l}\text { Published vegetation map produced by aerial photo } \\
\text { interpretation from 1:25000 images, in conjunction with } \\
\text { georeferenced field knowledge. [83]. }\end{array}$ & $\begin{array}{l}\text { Quantitative accuracy of the original map is } \\
\text { unmeasured. Map digitized and spatially } \\
\text { co-registered to } 2006 \text { map (Section 2.2). }\end{array}$ \\
\hline \multirow{4}{*}{$\begin{array}{l}\text { Finer-scale, inter-annual, } \\
\text { analyses } \\
\text { (Site II) }\end{array}$} & Para grass cover & $\begin{array}{l}2001,2004,2006 \\
2008,2010\end{array}$ & $\begin{array}{l}\text { This map series was produce from high spatial resolution } \\
\text { satellite imagery (Table 3) using a supervised, object-based, } \\
\text { classification (Section 2.3). Map accuracies were estimated } \\
\text { using separate image samples reserved for validation. }\end{array}$ & $\begin{array}{c}\text { Imagery/maps spatially co-registered to an } \\
\text { accurately georectified (2006 QuickBird imagery) } \\
\text { with horizontal accuracy approximately } \pm 2.5 \mathrm{~m} \text {. } \\
\text { Overall classification accuracies were } \geq 96 \% \\
\text { (Table 2, results). }\end{array}$ \\
\hline & Para grass Cover & 1991, 1996 & $\begin{array}{l}\text { Map produced by aerial photo interpretation of 1:25000 } \\
\text { images, with georeferenced ground surveys of vegetation } \\
\text { used to validate interpretations. Published methods [19]. }\end{array}$ & $\begin{array}{l}\text { Quantitative accuracy of the original } \\
\text { imagery/maps is unmeasured. }\end{array}$ \\
\hline & Water Depth & 2006 & $\begin{array}{c}\text { A depth model of site I, extracted for Site II analyses. } \\
\text { Modeled by regression between a Landsat dry-season } \\
\text { composite and georefereced floodplain depth records. } \\
\text { Published methods [51]. }\end{array}$ & $\begin{array}{c}\text { Horizontal accuracy } \pm 30 \mathrm{~m} . \\
\text { Depth prediction strength } \mathrm{R}^{2}=0.67, p<0.0001, n \\
=254 . \text { Mapped at a spatial resolution of } 30 \mathrm{~m} . \\
\text { Predicted depths ranged from } 0 \text { to } 1.85 \mathrm{~m} \text { in } \\
\text { increments of } 0.1 \mathrm{~m} .\end{array}$ \\
\hline & Fire Scar maps & $\begin{array}{l}2000,2003,2005 \\
2007,2009\end{array}$ & $\begin{array}{l}\text { Maps produced by object-based image analysis of Landsat } \\
\text { (available dry-season imagery) using the Nearest Neighbour } \\
\text { classifier. Published methods [51]. }\end{array}$ & $\begin{array}{l}\text { Horizontal accuracy } \pm 30 \text { m pixels. } \\
\text { Overall classification accuracies for map series: } \\
98 \%, 99.6 \%, 93 \%, 99 \% \text { and } 99 \% \text { respectively. }\end{array}$ \\
\hline
\end{tabular}


Table 2. Wetland vegetation types sampled from the satellite imagery (years 2001 to 2010). Vegetation cover descriptions are summarized from Boyden et al. 2013 [20].

\begin{tabular}{c|c}
\hline Model Training Class & Sampled Vegetation Cover Types \\
\hline Para grass & Urochloa mutica: dense cover, near mono-culture-wet and dry phases \\
\hline \multirow{4}{*}{ Non-para grass } & Native perennial grasses and floating vegetation mats: Dense vegetative cover dominated by Hymenachne acutigluma or Leersi hexandra \\
\cline { 2 - 2 } & $\begin{array}{c}\text { Annual grasses and sparse native perennial grasses, and ephemeral sedges: Oryza meriondalis, Pseudoraphis spinecens and E. dulcis (native rice, } \\
\text { mud-grass and water chestnut) }\end{array}$ \\
\cline { 2 - 2 } & Non-floodplain grasses and bare ground \\
\cline { 2 - 2 } & Sedges: Dense vegetative cover of perennial and ephemeral sedges (e.g., Eleocharis sphacelata and E. dulcis) \\
\cline { 2 - 2 } & Open water Lilies dominated by Nymphaea or Nymphoides spp. \\
\cline { 2 - 2 } & Nelumbo nucifera (red lily) \\
\cline { 2 - 2 } & Melaleuca (paperbark trees) \\
\hline
\end{tabular}


Table 3. Characteristics of the high-resolution image datasets used in production of the vegetation map time-series produced for between 2001 and 2010.

\begin{tabular}{|c|c|c|c|c|c|}
\hline Sensor & Spatial Resolution & $\begin{array}{l}\text { Analysis } \\
\text { Resolution }\end{array}$ & Spectral Characteristics & Acquisition Date(s) & Additional Notes \\
\hline IKONOS & $\begin{array}{l}\text { Pixel size: } \\
0.8 \mathrm{~m} \text { (pan) } \\
4 \mathrm{~m}(\mathrm{MS}) \\
\text { All bands were } \\
\text { provided at } 1 \mathrm{~m}\end{array}$ & $0.6 \mathrm{~m}$ & $\begin{array}{l}\text { Band 1: 445-516 nm (Blue) } \\
\text { Band 2: } 506-595 \mathrm{~nm} \text { (Green) } \\
\text { Band 3: } 632-698 \mathrm{~nm} \text { (Red) } \\
\text { Band 4: } 757-853 \mathrm{~nm} \text { (Near-IR) } \\
\text { Pan: } \quad 450-900 \mathrm{~nm} \\
\text { Dynamic range: } 11 \mathrm{bit}\end{array}$ & 03-06-2001 & $\begin{array}{l}\text { Data geo-rectified and } \\
\text { resampled to } 1 \mathrm{~m} \text { [84] }\end{array}$ \\
\hline \multirow{3}{*}{ QuickBird } & \multirow{3}{*}{$\begin{array}{c}\text { Pixel size: } \\
0.6 \mathrm{~m} \text { (pan and } \\
\text { pan-sharped bands), } \\
2.4 \mathrm{~m} \text { (MS) }\end{array}$} & \multirow{3}{*}{$0.6 \mathrm{~m}$} & \multirow{3}{*}{$\begin{array}{l}\text { Band 1: } 450-520 \mathrm{~nm} \text { (Blue) } \\
\text { Band 2: } 520-600 \mathrm{~nm} \text { (Green) } \\
\text { Band 3: } 630-690 \mathrm{~nm} \text { (Red) } \\
\text { Band 4: } 760-900 \mathrm{~nm} \text { (Near-IR) } \\
\text { Pan: } \quad 445-900 \mathrm{~nm} \\
\text { Dynamic range: } 11 \mathrm{bit}\end{array}$} & $25-06-2004$ & $\begin{array}{c}\text { panchromatic }+4 \text {-band } \\
\text { multispectral product }\end{array}$ \\
\hline & & & & $\begin{array}{l}23-06-2006 \\
24-07-2006\end{array}$ & $\begin{array}{l}\text { 4-band, UNB-pan-sharpened } \\
\text { mosaic geo-rectified to ground } \\
\text { control and used as the base } \\
\text { image for spatial co-registration }\end{array}$ \\
\hline & & & & $15-06-2008$ & UNB-pansharpened \\
\hline WorldView-2 & $\begin{array}{l}\text { Pixel size: } \\
0.49 \text { m (pan) } \\
2.4 \text { m (MS) }\end{array}$ & $0.6 \mathrm{~m}$ & 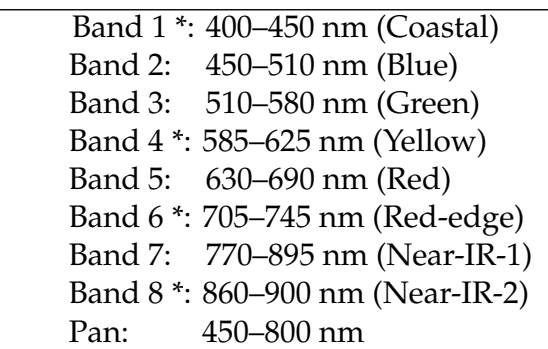 & $15-05-2010$ & $\begin{array}{l}\text { panchromatic }+8 \text {-band } \\
\text { multispectral product. Two } \\
\text { separate scenes (Region } 1 \\
\text { and } 2)\end{array}$ \\
\hline
\end{tabular}

multispectral data. * Indicates bands excluded from image analyses (WorldView-2 only). 


\subsection{Native Vegetation Displaced by Para Grass from 1986 to 2006 (Site I)}

An original A3-size hardcopy of the 1986 map [83] was scanned at 1000 DPI then co-registered to the 2006 map [20] using image-to-image warping applied in ENVI ${ }^{\circledR}$ ver. 4.8 [85]. This step used 613 control points manually selected from identifiable features of the July 2006 Landsat 5 TM image (i.e., the same base-image used to create the 2006 map). This color map was then segmented in eCognition ${ }^{\circledR}$ ver. 8.64 and labeled according to Finlayson (1989) using the manual editing tool [86]. Contiguous segments with identical class-labels were merged. A shapefile of the map was imported to ArcMap ${ }^{\circledR}$ ver. 9.3.1 [87]. A number of the vegetation classes of the 1989 map were also merged to simplify the vegetation change calculations (i.e., a single 'Paperbark' class was created from the two related sub-classes; and three classes, representing $<6 \%$ of total displaced area in total, were merged and named 'other').

Using the layer-intersect tool of ESRI ArcMap ${ }^{\circledR}$ ver. 10.1, the area of native vegetation displaced by para grass was determined by subtracting the para grass areas, mapped in 2006, from each intersecting 1986 map classes. Change-area estimates for each native-vegetation class are reported in hectares and as a proportion of their total areas. We omitted small boundary errors from analyses, evident between the outer boundary of both maps (i.e., between terrestrial and wetland areas).

\subsection{Production and Accuracy Assessment of Para Grass Map Series from 2001 to 2010 (Site II)}

As summarized in Figure 2, this section describes the steps involved in production and accuracy assessment of para grass maps produced for Site II.; years 2001 to 2010, by object-based image analysis (OBIA).

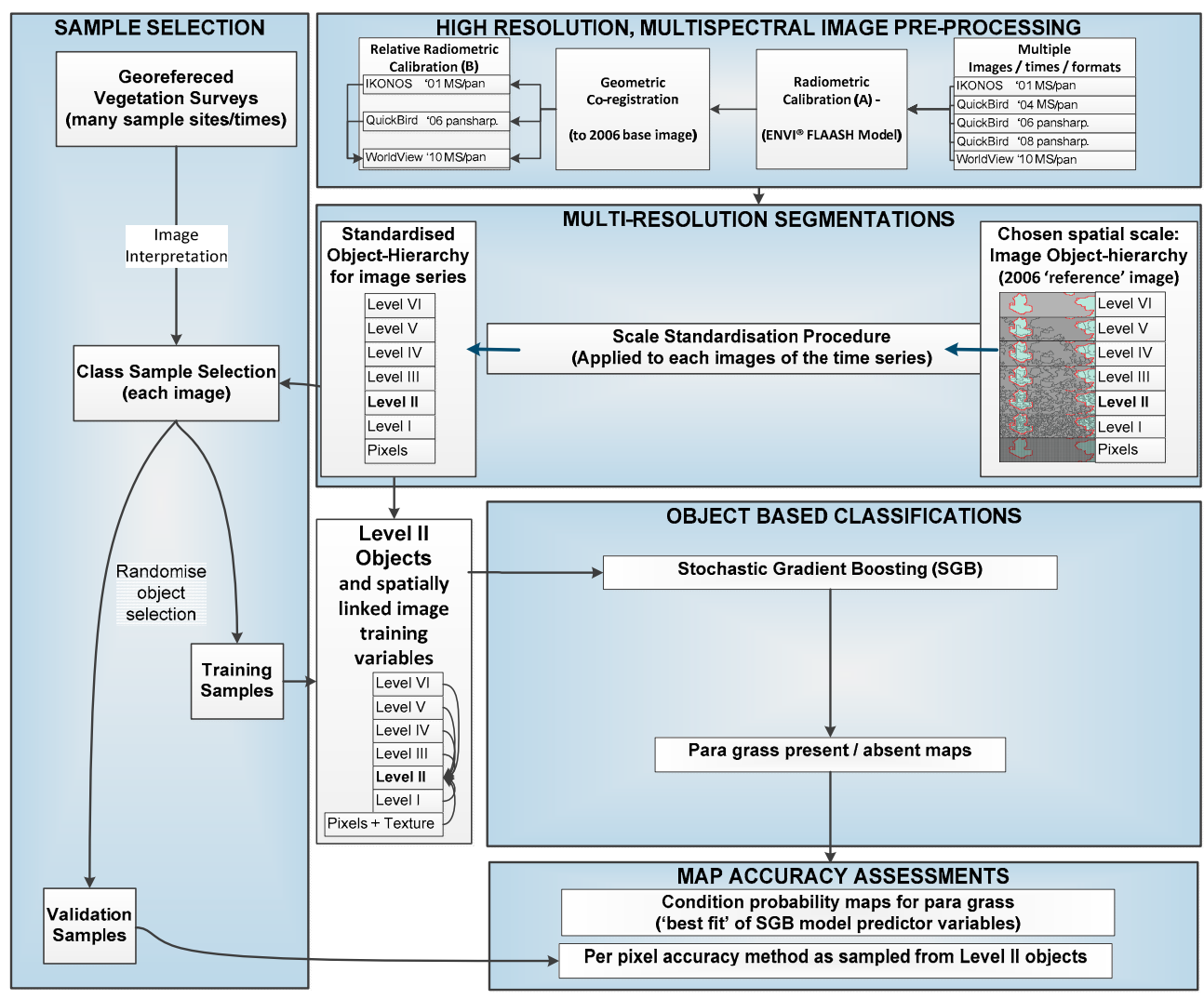

Figure 2. Steps involved in the production of para grass presence-absence maps (2002-2010) by supervised object-based image analysis (OBIA) using stochastic gradient boosting (SGB) and assessment of classification map accuracies. 
Using Trimble eCognition ${ }^{\circledR}$, a multi-level 'reference' segmentation was first produced from the 2006 image using a 'bottom up' segmentation [86,88]. In this step, segmentation scale parameters were chosen using a systematic 'trial and error' approach, with the objective of producing image objects of suitable scale and accuracy for subsequent classification. For each other image in the time series, scale parameters were adjusted to match the 'reference', based on the total number of image objects produced for the total scene area at each segmentation level [88].

A classification model was then built for each single-date image using the machine-learning algorithm, stochastic gradient boosting (SGB). The SGB method has been applied in several remote sensing studies and produced high image classification accuracies [89-92]. The algorithm recursively builds an ensemble or 'grove' of many independent classification and regression trees (CART) then combines them in a single classification model $[93,94]$. The process uses statistical bagging and boosting methods to optimize classification tree rules [93,95]. Bagging, also known as bootstrap aggregation, refers to the process of repeated, random selection of a separate subset of data to train each separate CART model [96]. Boosting refers to an additional process for the weighted selection of each new training data subset taken after each CART iteration. This adaptive weighting process uses an updated probability distribution of samples calculated from the residual error determined in the last model iteration. It places more weight on samples that were classified poorly in previous iterations [96]. By also applying the bagging procedure, the SGB method is resistant to model over-fitting $[90,97]$. It is a non-parametric method and does not rely on the assumption of normal distribution in data. In this context, the method is resilient to error arising from inaccurate training data, outliers and unbalanced sample data [98,99].

Image training samples for the SGB models were chosen from known para grass and non-para grass areas as defined in field surveys undertaken by airboat and helicopter (Figure 3 and Table 2). Image sample selection and subsequent classifications were conducted at the spatial scale of Level II image segmentations $[88,100]$. In this context, the mean size of sample objects used to train para grass was $16.3 \mathrm{~m}^{2} \pm 14.3 \mathrm{SD}$. Selection of image samples was aided using the pan-sharpened, true-color and false-color image composites of each image. In this regard, visually selected sample objects were then validated with georeferenced photos vegetation and descriptions gathered by trained field observers.

\subsubsection{Estimating Trends and Variability in Para Grass Cover (Site II)}

Linear regression was applied to assess trends and variability in total para grass cover (ha), over time (yr.) and in relation to water-depth habitat of the floodplain. These analyses were undertaken on data from the nine year study period $(2001-2010, n=5)$. We then repeated the regression on data spanning nineteen years (1991-2010), with historic para grass data included (years 1991 and 1996). In this analysis an outlier was removed (the 2004 datum), to be discussed further in the results.

The para grass cover maps (including several different derived indices); water depth and fire history maps were analyzed using the Zone-statistics function of Spatial Analyst Tools of ArcMap ${ }^{\circledR}$ ver. 9.3.1 (Figure 4). To do this 'zones' were assigned using a regularly spaced hexagonal sample lattice with sample-cell areas of 0.21 ha with a cell-height of $50 \mathrm{~m}$. This sample size was chosen because we considered it to be the minimum size that: (a) could be used to re-sample finer scale measurements without causing significant edge-effect errors; and (b) it was of a practical scale for future monitoring and applied research directed towards optimization of weed control operations or trials. Hexagonal resampling has also been shown to have better spatial sample efficiency due to symmetry with nearest neighbors and is visually less biased for displaying density-maps than square grids [101,102]. 

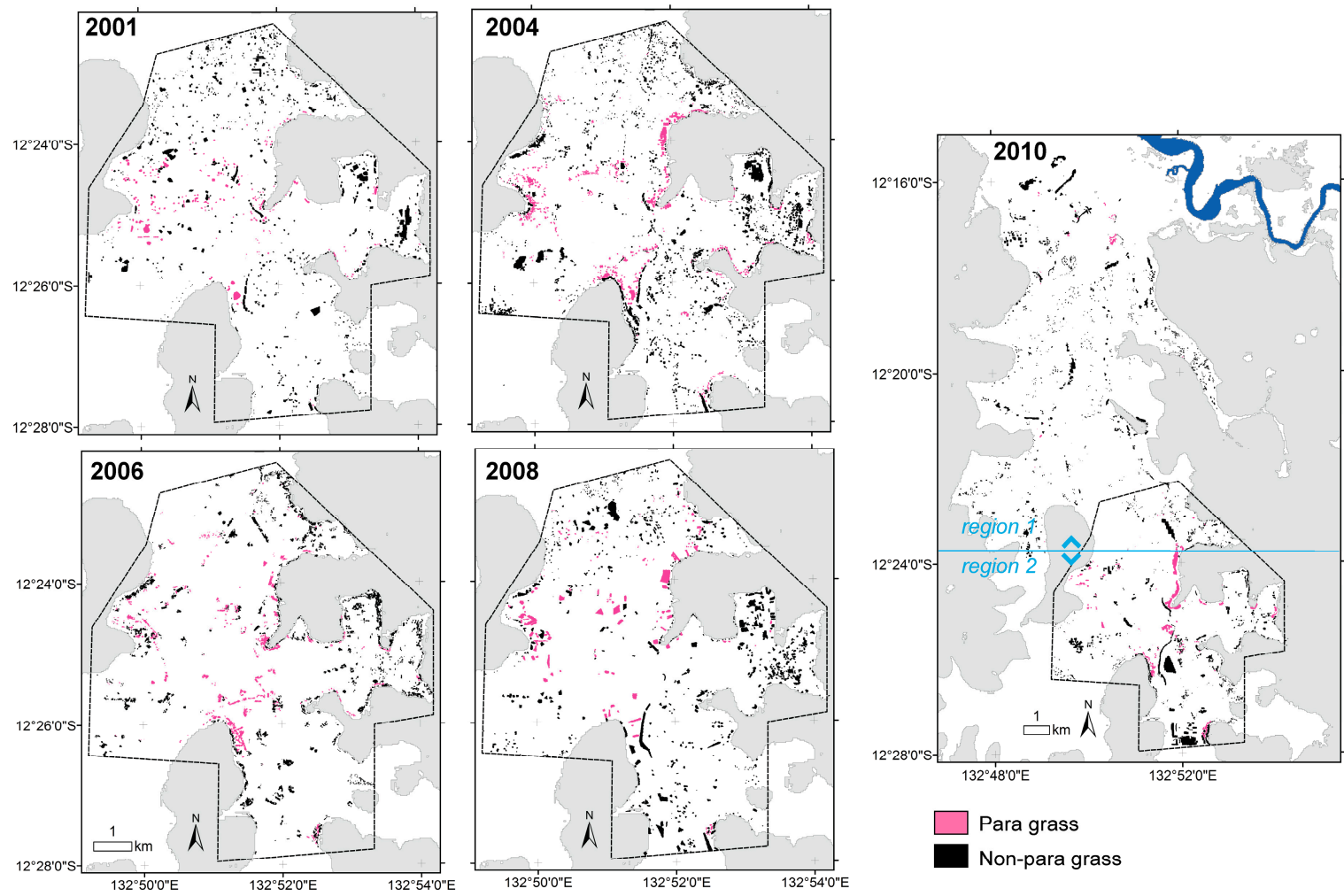

Figure 3. The distribution of sample-object clusters as selected and used for supervised classification (training) or reserved for validation of resulting present-absent classification maps for para grass (years 2001 to 2010).

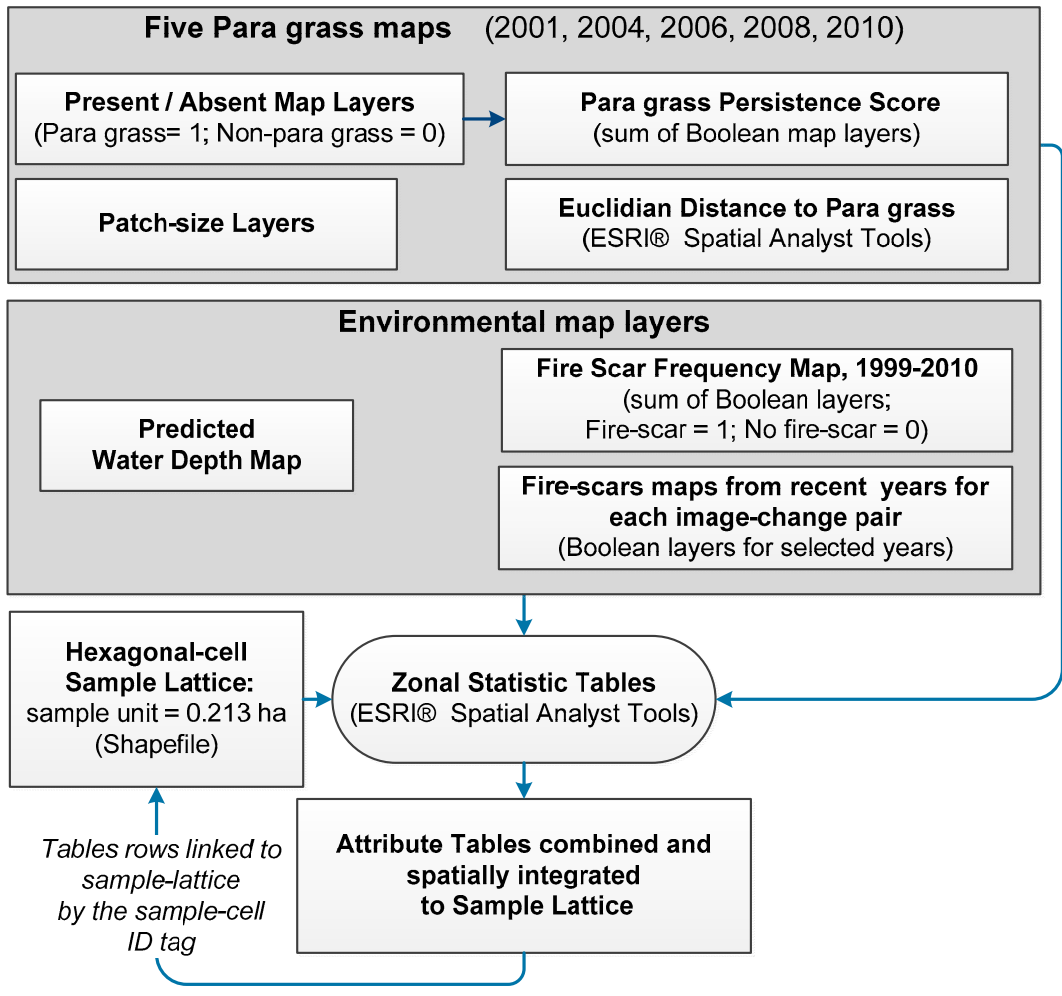

Figure 4. Methods used to calculate and integrate para grass and environmental layer datasets using a hexagonal sample lattice and zonal statistics. 
The several spatial and temporal indices derived for para grass (Table 4), enabled change in para grass cover to be characterized across multiple scales. These indices represent either local- or patch-scale traits. Local-scale traits included: (a) The presence/absence of para grass, measured at the standardized spatial scale of the map productions; and (b) the percentage cover-density, measured within larger-scale, hexagonal, sample cells ( 0.21 ha) of a sample lattice. Patch-scale indices included the area of discrete patches; inter-patch distance; the 'cumulative persistence score', over time (i.e., the sum of all para grass from all high-spatial resolution map layers); and the distances to most 'persistent' patches.

Indices relating to changes in density and inter-patch distance of para grass were also calculated for a series of four 'image-difference' pairs 2001-04, 2004-06, 2006-08 and 2008-10 (refer to Equations (1), (2) and (3)).

Firstly, para grass sample-cell density was calculated for each map of the time-series (Equation (1)):

$$
P C_{t i}=\left(\frac{S_{t i}}{C t i}\right) * 100
$$

where $P C_{t i}$ is percentage cover in cell $i$ for para grass classification layer $t ; S_{t i}$ is the sum of all para grass pixels falling within cell $i$ and $C$ is the total count of all pixels (para grass and non-para grass classes) from layer $t$ falling in cell $i$. Cell-density was also color-coded for the purpose of cartographic illustration.

Then, from each of image-difference pair representing the near-biennial time intervals of the series (2001-04, 2004-06, 2006-08 and 2008-10), two indices relating to changes in cover-density and the distance between para grass patches were calculated (Equations (2) and (3)):

$$
\text { Change in Density } \mathrm{i}_{\mathrm{i}}=\mathrm{PC}_{\mathrm{it}_{1}}-\mathrm{PC}_{\mathrm{it}_{0}}
$$

where Change in Density in cell $i$ is the difference in $P C$ (percentage cover, Equation (1)) measured in that cell between at $t_{1}$ and $t_{0}$ (i.e., representing each image-difference pairs, above).

$$
\text { Change in Interpatch Distance } \mathrm{i}_{\mathrm{i}}=\mathrm{PD}_{\mathrm{it}_{1}}-\mathrm{PD}_{\mathrm{it}_{0}} \text {, }
$$

where Change in Interpatch Distance is the difference in the mean distance between patches boundaries $(P D)$ in cell $i$ measured between at $t_{0}$ and $t_{1}$ (representing each image-difference pair, above).

The local Moran's statistic was applied in ESRI ArcMap (ver. 9.3.1) to the mean the 'change in density' map [87]. This statistic identifies spatial clusters that differ significantly from a random distribution of the same values array [103]. We used a fixed search distance of $50 \mathrm{~m}$ in this analysis. Areas of either significant positive or negative change are referred to as 'hot-spots' and 'cold-spots' respectively. Hot- and cold-spots were then compared to depth habitat area using a one-way ANOVA.

The spatial and temporal patterns in para grass were correlated with the maps of water depth and fire history. Indices for para grass density and change in density were plotted across the depth gradient as the mean for the total sample period, each sample year and each image-difference pair. The number and total area of sample cells within each water depth interval bin and each ANOVA depth category (Shallow, Moderate and Deep) are shown in Figure 5. In this regard, sample cells containing zero para grass over the entire sampling period (from 2001 to 2010) were omitted from all analyses. 
Table 4. The vegetation and habitat indices used in the analysis of para grass change over Site II from 2001 to 2010.

\begin{tabular}{|c|c|c|c|}
\hline Group & Variable & Description & Derivation \\
\hline \multirow{5}{*}{ Para Grass } & Cumulative Persistence Score (CPS) & The persistence of para grass at any one location, over time (2001 to 2010). & $\begin{array}{l}\text { The sum of binary map layers for para grass presence using } \\
\text { maps 2001, 2004, 2006, } 2008 \text { and } 2010 \text { (i.e., present }=1 \text {, or } \\
\text { not present }=0 \text { ). }\end{array}$ \\
\hline & $\begin{array}{l}\text { (a) Cell-density, and (b) change in } \\
\text { cell-densities }\end{array}$ & $\begin{array}{l}\text { (a) The percentage of para grass cover measured within each } 0.24 \text { ha, } \\
\text { hexagonal, sample cell of each map layer (2001, 2004, 2006, 2008, and 2010); } \\
\text { and (b) the negative or positive change in cell-densities, calculated for each } \\
\text { image-difference pair in series: 2001-04, 2004-06, 2006-08 and 2008-10. }\end{array}$ & $\begin{array}{l}\text { Percentage cover calculated based on the number of para } \\
\text { grass pixels as a proportion of the total number of pixels } \\
\text { within a hexagonal cell. Change in cover then calculated by } \\
\text { subtraction for image-difference pair (please refer to } \\
\text { Equations (1) and (2), below). }\end{array}$ \\
\hline & $\begin{array}{l}\text { Distance to patch and change in } \\
\text { patch distance }\end{array}$ & $\begin{array}{l}\text { The Euclidean distances (m) to nearest discrete para grass 'patch' over } \\
\text { time, } 2001 \text { to } 2010 \text {. Changes in patch distances were also measured for } \\
\text { each image-pair in series: 2001-04, 2004-06, 2006-08 and 2008-10 and } \\
\text { denoted as either an increase }(+) \text { or decrease }(-) \text { in distance. }\end{array}$ & $\begin{array}{l}\text { The Euclidean distance function applied at } 1 \mathrm{~m} \text { resolution } \\
\text { to each map. Zone statistics were then derived for each } \\
\text { layer from the hexagonal sample matrix. Refer to Equation } \\
\text { (3), below for the 'change in distance' calculation. }\end{array}$ \\
\hline & Distance to 'Permanent' Patch & $\begin{array}{l}\text { The Euclidean distances }(\mathrm{m}) \text { to the nearest 'Permanent' patch, defined as } \\
\text { patches with a possible maximum cumulative persistence score (CPS) of } 5\end{array}$ & $\begin{array}{l}\text { Euclidean distance function applied at } 1 \mathrm{~m} \text { resolution. The } \\
\text { spatial analyst 'Reclass' function was used to generate the } \\
\text { CPS map layer. }\end{array}$ \\
\hline & Patch Size & $\begin{array}{l}\text { Contiguous areas classified as para grass. Patch sizes (ha) were calculated } \\
\text { for each classification layer: 2001, 2004, 2006, } 2008 \text { and } 2010 \text {. }\end{array}$ & $\begin{array}{l}\text { Patch areas (ha) calculated from polygon layers generated } \\
\text { for all classifications. Georeferenced zone statistics (mean } \\
\text { and maximum) were calculated for each respective layer } \\
\text { using the hexagonal sample lattice. }\end{array}$ \\
\hline \multirow[t]{2}{*}{ Other } & Depth habitat & $\begin{array}{l}\text { Used in the analysis of variance (ANOVA) of para grass change in relation } \\
\text { to three depth categories: 'Shallow', 'Moderate' and 'Deep'. Selection of } \\
\text { the depth ranges of each depth category were based on the distribution of } \\
\text { para grass in relation mapped depth [51\}. }\end{array}$ & \\
\hline & Previous dry-season fire & $\begin{array}{l}\text { The burnt (or unburnt) areas mapped in the first dry-season period } \\
\text { between each image- difference pair (i.e., 2001-04, 2004-06, 2006-08 and } \\
\text { 2008-10.) }\end{array}$ & $\begin{array}{l}\text { The fire-scar maps derived from Landsat representing years } \\
2003,2005,2007 \text { and } 2009 \text { [51]. }\end{array}$ \\
\hline
\end{tabular}




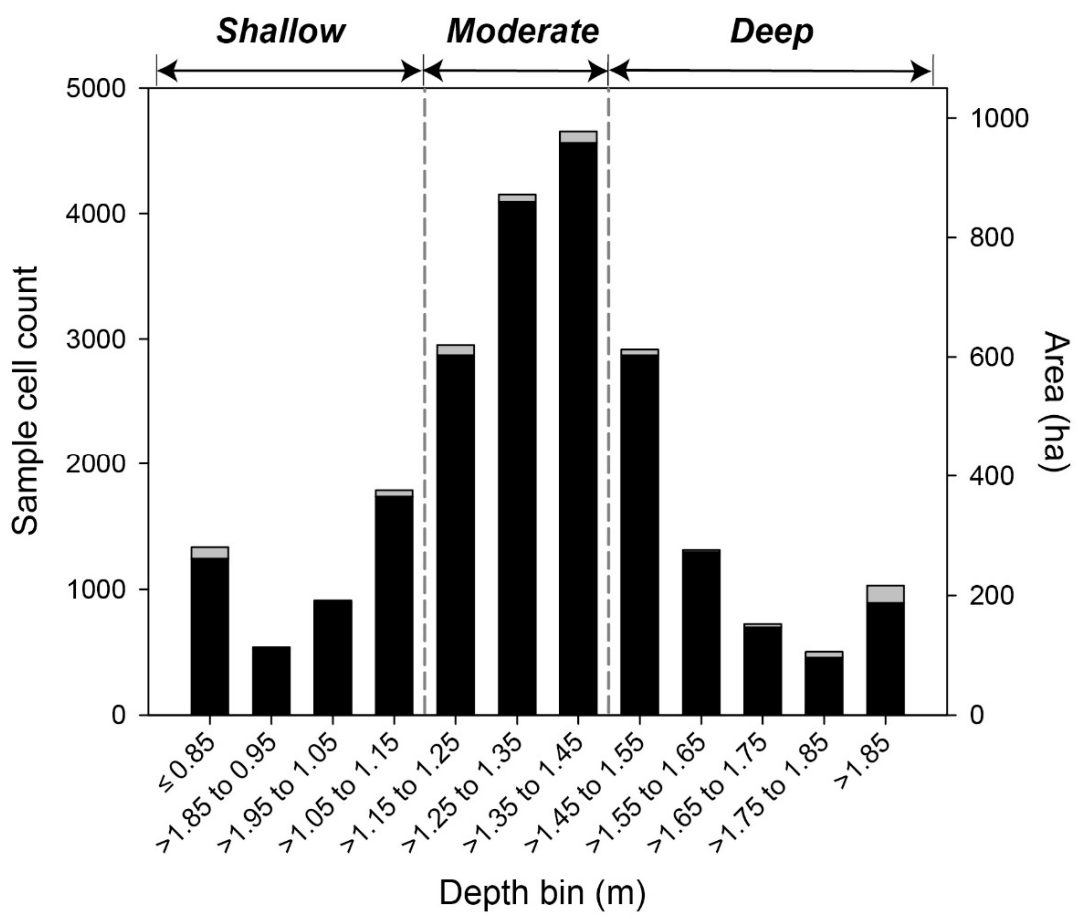

Figure 5. The mapped depth categories (shallow, moderate and deep) tested in the ANOVA and the number of hexagonal sample-cells within each depth-interval bin across Site II. Data used for the ANOVA were only taken from sample-cells where para grass was 'present' (black bars). Sample cells with a complete absence of para grass over the sample period were omitted from the analysis (i.e., stacked grey bars).

Linear regression was also applied to compare the rate of annual change in para grass cover in shallow $(\leq 1.15 \mathrm{~m})$, moderate $(>1.15$ to $<1.45 \mathrm{~m})$ and deep $(\geq 1.45 \mathrm{~m})$ water depth habitats. These depth ranges were selected to reflect major differences in total cover of para grass across the depth gradient as mapped in 2006, Site I [51]. In this regard, the total cover of para grass was known to be greatest within the depth-range of the moderate depth category. Two estimates of the linear rate of change in para grass cover were then calculated. First, changes in total extant para grass cover were measured across the 5-image series. Second, the cumulative spatial footprint of para grass was measured. This measure included attrition in para grass between years.

The potential influences of water depth and fire habitat on para grass dynamics were tested using a two-way factorial analysis of variance (ANOVA) applied in Statistica ${ }^{\circledR}[100]$. Change in para grass density and inter-patch distance (Equation (3)) were the variables used to evaluate the effects of the habitat parameters of water depth and fire on para grass dynamics. The dependent variables were calculated for each time interval of the four image-difference pairs. These data were pooled such that each cell of the sample lattice was replicated four times. Hence, the ANOVA design was assumed to be balanced in relation to effects of time on para grass variables. For consistency, the interval unit of change was 'biennial' with the one exception being a 3-year change interval for 2001-2004. Likewise, the time-interval between fire and post-fire para grass mapping was one wet season (i.e., about 1 year). In this analysis, we assumed that impacts of fire on para grass cover would be most apparent in relation to the most recent fire. Therefore, fire categories were chosen from each fire-year $(2003,2005,2007$ and 2009) to correspond with each respective image-difference pair (2001-2004, 2004-2006, 2006-2008 and 2008-2010). These categories were defined by the majority (of either burnt or unburnt classes by area) within each sample-cell on each fire-year map. 


\section{Results and Discussion}

\subsection{Native Vegetation Displaced by Para Grass from 1986 to 2006 (Site I)}

Para grass covered 1308 ha or 7\% of the total floodplain area in 2006 (Figure 6). Oryza was the most impacted of the native grassland communities mapped by Finlayson et al. (1989), with $\approx 471$ ha or $24 \%$ of its area displaced by para grass by 2006 . This was followed by native Hymenachne grassland $\approx 262$ ha $(20 \%)$, Pseudoraphis grassland $\approx 132$ ha $(5 \%)$ and Hymenachne-Eleocharis swamp $\approx 49$ ha (5\%). The largest para grass patches were associated with the Oryza and Hymenachne communities. Smaller patches were commonly associated with floodplain margins, displacing large areas of Pseudoraphis grassland. In this regard, similar native vegetation affiliations for para grass have been independently reported for the Magela Creek and the Mary River floodplains of Northern Territory, Australia [11,19,51,104-106].

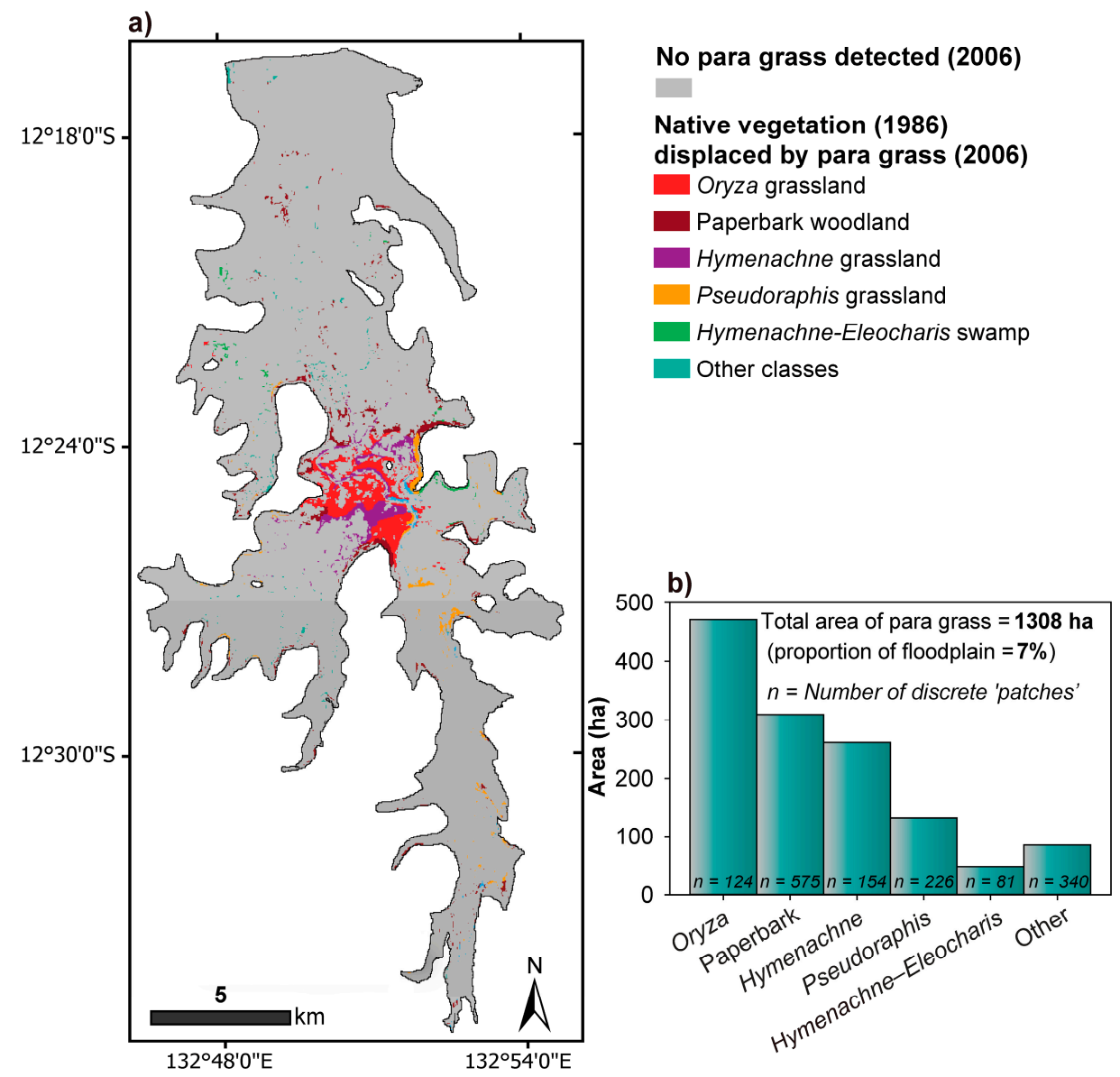

Figure 6. The estimated displacement of native vegetation communities by para grass between 1986 and 2006 shown as: (a) The distribution of dense para grass and the native communities displaced at 2006; and (b) the total area of the key vegetation communities displaced.

To some extent, the different scale and accuracies of maps used for this analysis limit the conclusions that can be drawn. For example, due to semantic limitations, the displacement of the paperbark woodland class (309 ha) by para grass, does not necessarily indicate a reduction in paperbark tree numbers. Nevertheless, this warrants further investigation as other authors' contest that grassy weeds can suppress woody recruitment in savannas. This may occur when such high-biomass weeds alter microsite conditions or lead to more frequent and severe fires $[11,107,108]$.

In addition, a spatial mismatch error of $\pm 120 \mathrm{~m}$ was detected between the two intersecting maps; as calculated by the root-mean-square statistic of the map co-registration process. Such an error may distort generalized estimates of native vegetation displacement, particularly when discreet map 
features are small or have narrow linear shapes [109]. However, in this case we do not think this error will have a major impact on the result for the following reasons. Firstly, most of the contributing area of para grass (mapped at high accuracy) is confined to just several larger discreet patches on the 2006 map. That is, while smaller patches of para grass mapped by Landsat (and within $120 \mathrm{~m}$ of the boundaries of 1986 map features) will be most prone to this mismatch error, they contributed little to the total area of para grass mapped. Secondly, the total area over which para grass was measured was large $\left(182 \mathrm{~km}^{2}\right)$ and measured from a map produced with high classification accuracy for para grass (96\%), and with an estimated spatial accuracy of $30 \mathrm{~m}$. Thirdly, most discreet features on the $1986 \mathrm{map}$ had large rounded shapes meaning the impact of spatial mismatch error of $120 \mathrm{~m}$ will be less significant.

\subsection{Production and Accuracy Assessment of Para Grass Map Series from 2001 to 2010 (Site II)}

The series of maps produced by SGB-OBIA classifications, including 'present-absent', and of conditional probability maps for para grass are shown in Figure 7 . In general, this method produced high classification accuracies for para grass (Table 5). However, there were notable inconsistencies between the classifications as highlighted by the 2004 image. In this case, conditional probabilities for para grass (based on the best fit produced from training variable inputs) appeared to be lower in comparison with other maps (Figure $7 \mathrm{~b}$ ). Potential inconsistencies between years in 'on-ground' data, used to train and validate each classification, or in the environmental conditions at the time of image capture, may have contributed to this anomaly. In the future, such uncertainties might be avoided by implementing where possible a more systematically stratified approach for the collection of adequate 'on-ground' samples across these large, relatively inaccessible, areas. In this context, integrated deployment of UAV (Unmanned Aerial Vehicles) with very high resolution, sensor technologies for 'on-ground' sampling can likely improve consistency and accuracy of satellite image mapping, over time [76].

a) Classification result (images years 2001-2010)

Para grass

Non-para grass
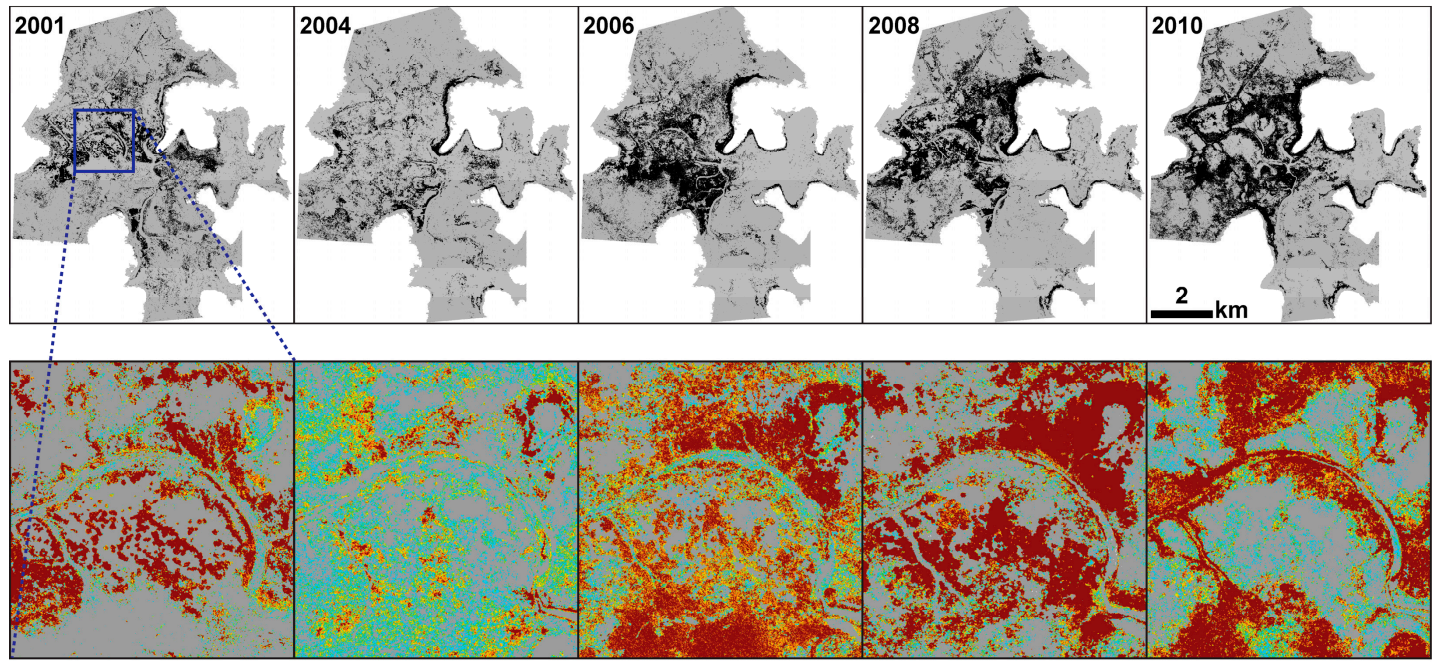

b) Para grass class conditional probability ranges

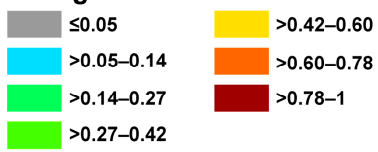

Figure 7. Site II maps produced from the five SGB-OBIA classification models (years 2001-2010) showing: (a) The 'presence-absence' classifications of dense para grass cover used in subsequent analyses; and (b) associated conditional probability maps for these classifications (inset area, example). 
Table 5. Accuracy statistics for the vegetation maps of the time-series (2001 to 2010) produced from the single-date SGB classification models and using the chosen set of 139 OBIA predictor variables.

\begin{tabular}{|c|c|c|c|c|c|c|c|c|c|c|c|}
\hline \multirow{2}{*}{$\begin{array}{l}\text { Class } \\
\text { Image }\end{array}$} & \multicolumn{3}{|c|}{ Number of Pixels } & \multicolumn{3}{|c|}{ Accuracy } & \multicolumn{3}{|c|}{ Kappa Statistic } & \multicolumn{2}{|c|}{ Error Rate (\%) } \\
\hline & Reference & Classified & Correct & Producers & Users & Overall & Producers & Users & Overall & Omission & Commission \\
\hline IKONOS (2001) & 410897 & 413727 & 377619 & 92 & 91 & 96 & 0.90 & 0.89 & 0.89 & 8 & 9 \\
\hline QuickBird (2004) & 707180 & 756735 & 664166 & 94 & 88 & 96 & 0.92 & 0.84 & 0.88 & 6 & 12 \\
\hline QuickBird (2006) & 617425 & 643414 & 590333 & 96 & 92 & 96 & 0.94 & 0.88 & 0.91 & 4 & 8 \\
\hline QuickBird (2008) & 625118 & 700247 & 618718 & 99 & 88 & 97 & 0.99 & 0.88 & 0.91 & 1 & 12 \\
\hline WorldView $\left(2010\right.$, R1 $\left.^{*}\right)$ & 86461 & 89831 & 74124 & 86 & 83 & 99 & 0.85 & 0.82 & 0.83 & 14 & 17 \\
\hline WorldView $\left(2010, \mathrm{R}^{*}\right)$ & 273762 & 279851 & 264567 & 96.6 & 95 & 97.6 & 0.95 & 0.93 & 0.94 & 3.4 & 5 \\
\hline
\end{tabular}




\subsection{Measuring Distribution Trends and Inter-Annual Dynamics of Para Grass (Site II).}

From 2001 to 2010, para grass cover increased by 540 ha from 747 to 1287 ha, a total change of $72 \%$ (Figure $8 \mathrm{a}-\mathrm{c}$ ). A distinct trend of increasing para grass was evident over the timeframe, underpinned by net increases of 145, 102 and 293 ha for the periods 2001-2006, 2006-2008 and 2008-2010, respectively. This trend was also consistent over the extended 18-year period, 1992-2010, with historical map records included [19]. The relationship between increasing para grass (ha) and time (years) was not significant $\left(\mathrm{R}^{2}=0.58, p=0.08, n=5\right)$ when all the 2001-2010 maps were included in analysis. However, the relationship was stronger if either the 2001 or the 2004 map was removed from the analysis (i.e., respectively $\mathrm{R}^{2}=0.95, p=0.02, n=4$ and $\mathrm{R}^{2}=0.81, p=0.07, n=4$ ). The relationship was strongest when results (less the 2004 outlier) were combined with the historical maps of para grass cover maps-Figure $8 c$, dashed line (i.e., $\mathrm{R}^{2}=0.96, p=0.0003$ ).
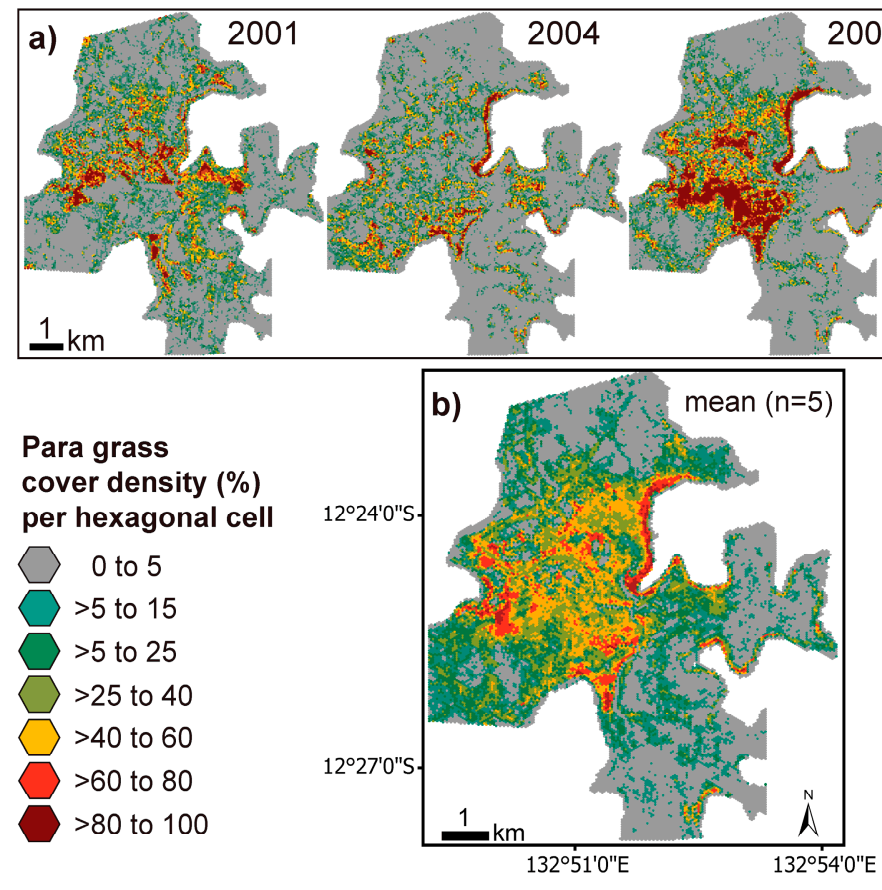
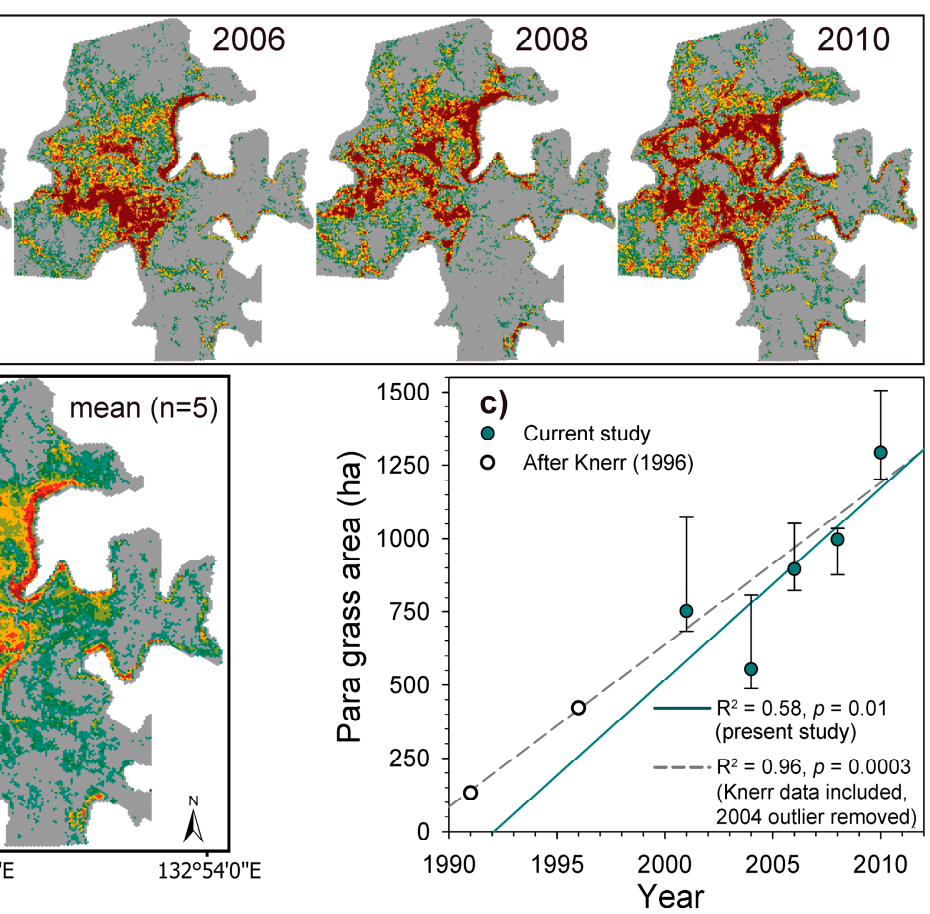

Figure 8. Para grass cover measurements (Site II) shown as: (a) The para grass cell density for each image from 2001 to 2010; (b) the mean cell density from these measurements ( $n=5$ image samples) and (c) as the total area (ha) of para grass over time (year) and including historic measurements (1991 and 1996) [19]. Note: Omission and commission error estimates only available for the recent maps, from 2001 to 2010 .

However, a net decline of 194 ha was also measured from 2001 to 2004 (Figure 8c). Changed hydrological conditions or fire disturbance might have contributed to these observed declines. Alternatively, the 2001 and 2004 image classifications might be less accurate than other classifications of the series due to a heavier reliance on reference samples selected by retrospective image interpretation [88].

The mean overall change in para grass density within sample cells was $+3.3 \%$ and net inter-annual change in density ranged from $-4.3 \%$ to $+8.9 \%$, as measured across the series of four image-difference pairs (Figure 9c). However, these statistics did not reflect the finer scale site-specific fluctuations in para grass cover occurring within areas where it had already established. The spatio-temporal variability of para grass in these areas was substantial, yet site-specific trends in cover increase or decrease were also apparent (Figure 9a,b). 

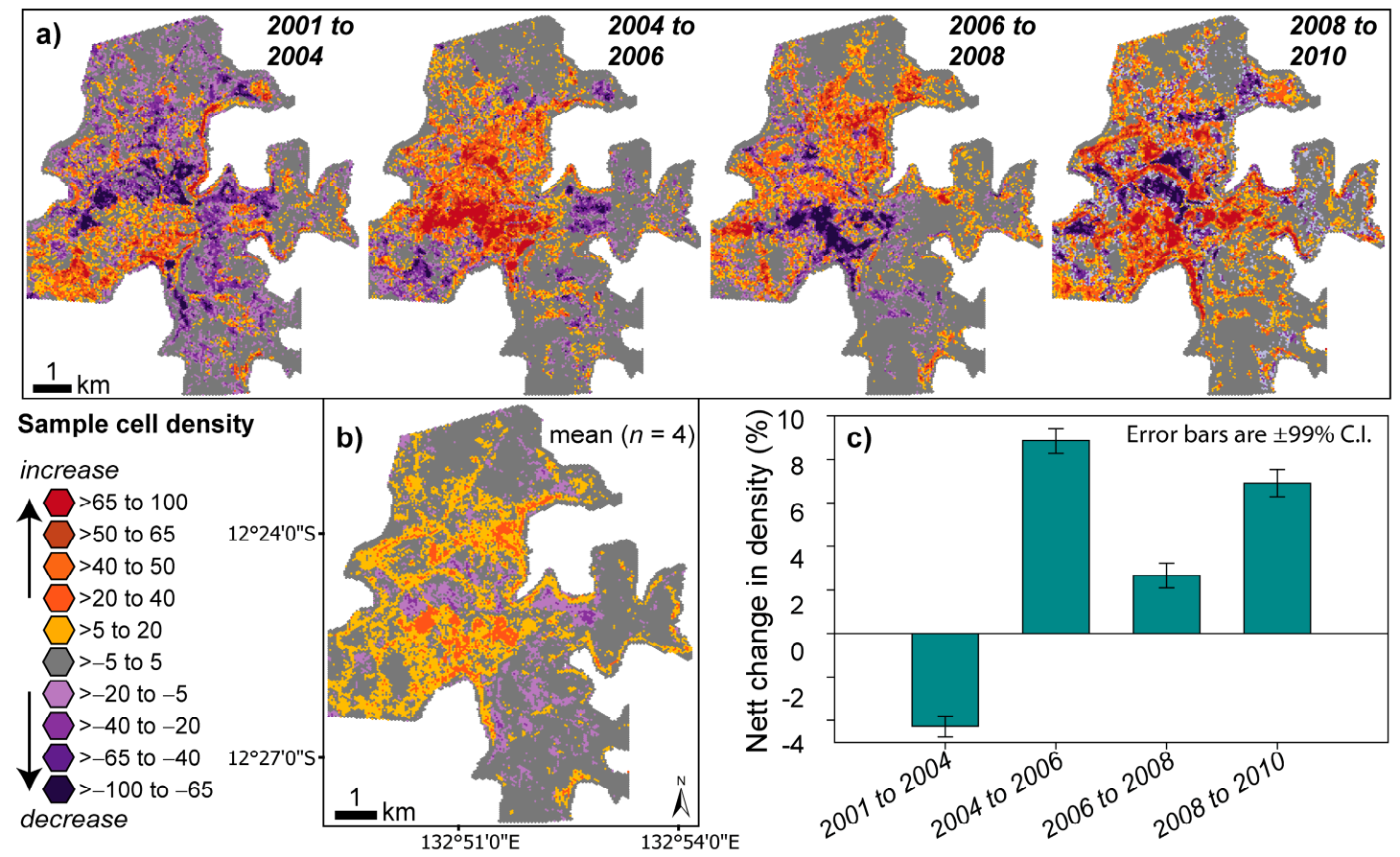

Figure 9. Change in para grass cell-density at Site II as: (a) Mapped in series for each image-difference pair; (b) a map of the mean change in density from all Image-Difference Pairs (IDPs) and as (c) the graphed mean net change for each IDP.

Mean 'hot-spots' and 'cold-spots' of change, measured by the local Moran's statistic, were also spatially clustered (Figure 10). Hot-spots (areas of increasing cover) occurred in shallower areas compared to cold-spots (areas of decreasing cover), although the mean difference in depth between these extremes was less than $0.1 \mathrm{~m}(t=6.8$, d.f. $=5487, p<0.0001)$. On average, hot-spot areas were much larger than cold-spot areas (138 ha \pm 2 SE compared to 23 ha \pm 1 SE.; respectively), contributing to the net increase in para grass cover. Hotspots were sometimes located along channel lines and associated levee banks on the floodplain. Raised levee banks are likely to enhance para grass growth because they may be more fertile, have a connection with permanent water and may support longer periods of aerobic root-metabolism of para grass [110,111].

The high inter-annual variability in annual wet season rainfall across the study period almost certainly influenced change and variability in para grass cover. In this regard, annual wet season rainfall ranged between 1111 and $2128 \mathrm{~mm}$ from 2001 to 2010 [112]. For the same period, the area of floodplain burnt annually ranged from near zero to 150,000 ha [51]. Between-year variation in hydroperiod and the spatial extent of this variation is also likely to influence the rates at which para grass distribution changes. For example, because the metabolism of para grass root systems are energetically most efficient under aerobic conditions, periods of soil inundation or, conversely, air-exposure, will influence attrition or production of para grass [111]

Extensive floodplain fires in the 2003 dry-season [51], followed by a late commencement of rain the following 2003/2004 wet-season [112] could have resulted in a reduction in para grass cover that favored the re-establishment of native vegetation cover in these areas. It has also been shown, for example, that Oryza re-establishment is facilitated by removal of para grass cover by fire [53] or mechanical means [8].

Large increases in the size of para grass patches occurred between 2001 and 2010, despite the localized fluctuations in para grass density, within patches (Figure 11a). From 2001 to 2004, the mean patch size was less than 2.5 ha, but grew from 40 to 50 ha between 2006 and 2008, and to almost 200 ha in 2010 (Figure 11b). These results imply that small patches eventually expand and coalesce with surrounding patches, completely replacing pre-existing vegetation. 


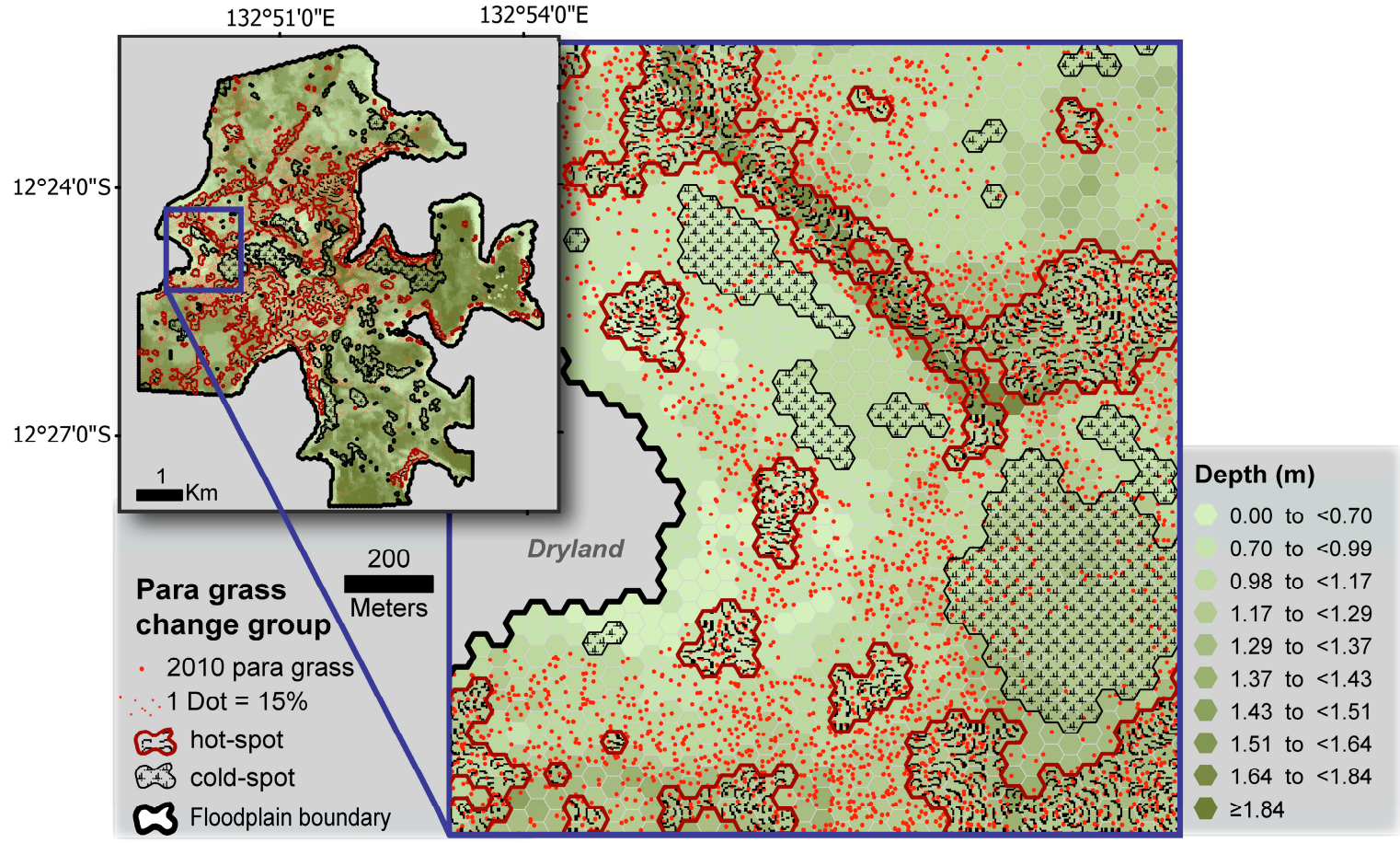

Figure 10. Localized trends in para grass cell-density at Site II as determined by the local Moran's statistic applied to the change in density data layer and overlaid in relation to predicted depth and a dot-density overlay of the last recorded para grass distribution in 2010.

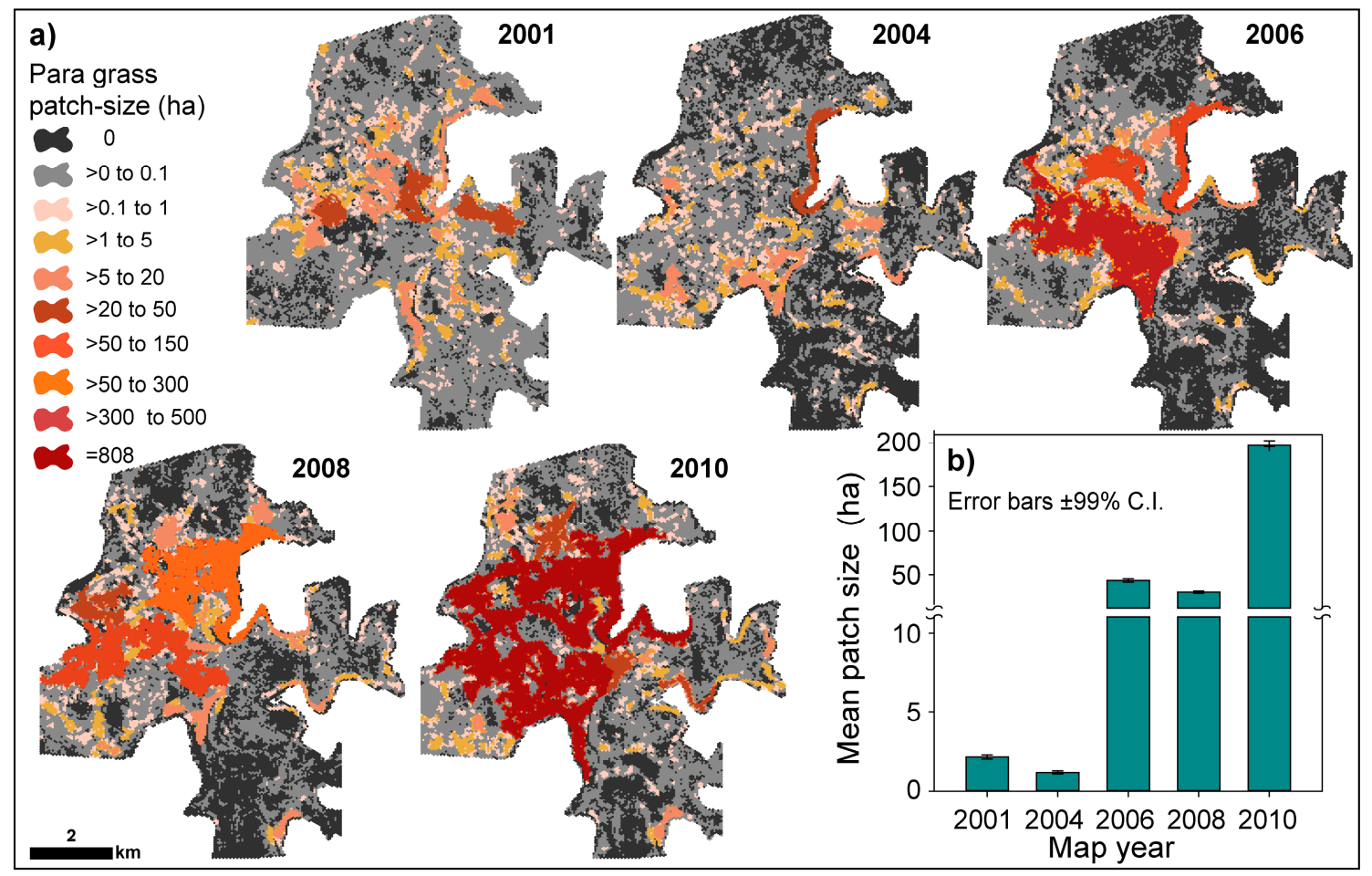

Figure 11. Changes in para grass patch-size (ha) at Site II from 2001 to 2010: (a) Mapped as the maximum patch-area by year; and (b) graphed as the mean patch area by year. Patch-size divisions were chosen manually, with a point of separating larger patch increases and areas that may represent zero para grass and higher likelihood of commission error ( $>0$ to 0.1 ha). 
In other areas, the size of para grass patches fluctuated in time between zero to less than 0.1 ha in size (Figure 11a). In these areas sample cells including 'small patches', with an overall density of $<5 \%$, are likely to represent classification noise (i.e., para grass commission error). This level of error is consistent with accuracy statistics generated for the individual maps (Table 5, above). In this regard, future research might investigate the screening out of classification error based on smaller patch size to yield a more robust measurement of change.

Rates of increase in para grass cover correlated strongly with the depth-habitat profile for Site II (Figure 12). While cover density varied substantially between years, mean density peaked within the 0.5-1.5 m depth range (Figure 12b). Density fluctuations were greatest within the 1.5 to $2.5 \mathrm{~m}$ range, while the scale of change in cover density was greatest in the 1.0 to $1.3 \mathrm{~m}$ depth-zone (Figure 12d).
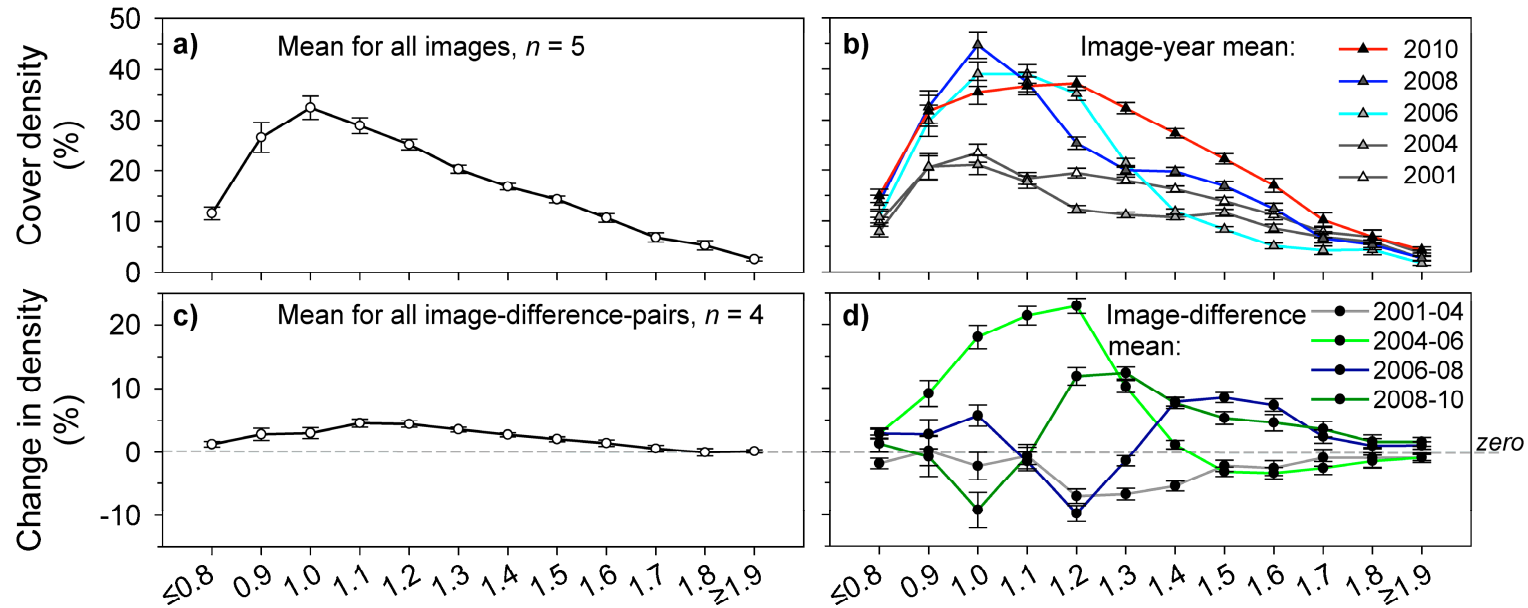

Floodplain depths, March 2009 (m)

Figure 12. Para grass cover densities (\%) from 2001 to 2010 in relation to depth over Site II as measured from the 0.24 ha sample-cell lattice and defined by: (a) mean densities from all present-absent maps; (b) mean densities from each individual map; (c) the 'change-in-density' means from all Image Difference Pairs; and (d) the change-in-density means from each individual IDP. The representation of depthsand low/high extremes as predicted for March 2009 [51]. Error bars are the 99\% confidence interval.

As summarized in Figure 13 and Table 6, para grass spread most quickly through the moderate depth habitat $(>1.15$ to $1.4 \mathrm{~m}$ ) compared to the shallow and deep depth habitats $(\leq 1.15$ and $>1.4 \mathrm{~m}$, respectively;). The average increase in total 'extant' para grass cover within the moderate depth habitat area was estimated to be 37 ha per year (Figure 13a). The cumulative spatial footprint of para grass (i.e., 'extant' + 'extinct' cover) within the moderate habitat was 95 ha per year, almost three times the year-total rate of increase in the extant cover (Figure 13b). suggest that para grass percolated most quickly through the moderate depth habitat, but that attrition in para grass cover also occurred in this habitat, at an average rate of 58 ha per year.

The spread of para grass was slower in the shallow habitat, while its cover-density was nevertheless greatest (Figures 12a and 13). This suggests that its capacity to establish stable, spatially persistent, patches is greater within this habitat. By contrast, within the moderate depth habitat, growth rates were higher but the difference between historical and extant para grass cover was also greater. Therefore, while rates of para grass growth were, on average, greater in this habitat, colonies also appeared to be more frequently disrupted. A regime of more frequent disturbance within this habitat area might be causing these fluctuations. For example, these areas might be subject more severe seasonal fires or hydrological conditions (e.g., a prolonged flood inundation period) that may cause para grass to be reduced in density. 


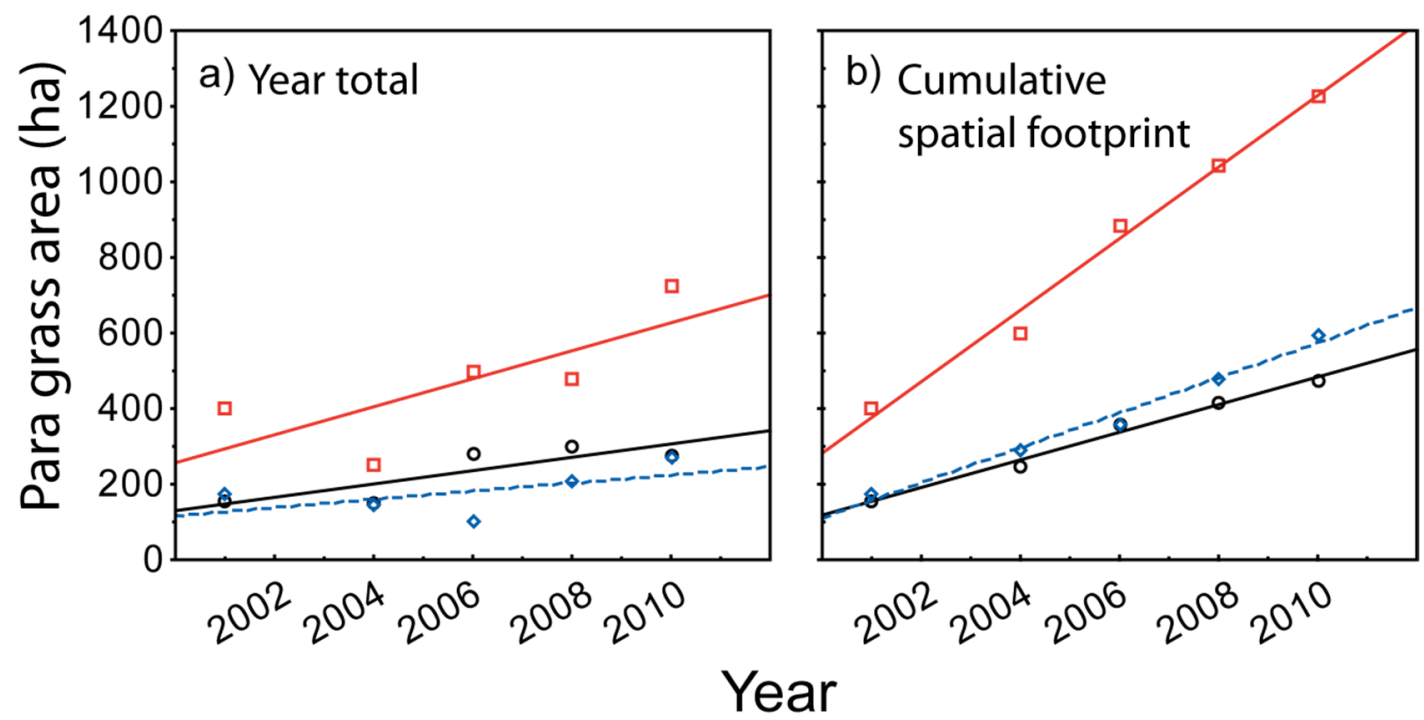

Figure 13. Changes in para grass cover within 'shallow', 'moderate' and 'deep' depth water habitats at Site II as calculated from: (a) The total mapped para grass cover for each year; and (b) the cumulative spatial footprint of para grass cover over time, calculated in series, sequentially, from 2002 to 2010. The symbols for shallow, moderate and deep categories on the graph are defined in Table 6, below.

Table 6. Regression statistics for the estimated rates of rates para grass cover increase within 'shallow', 'moderate' and 'deep' depth water habitats at Site II as calculated from Figure 13.

\begin{tabular}{|c|c|c|c|c|c|c|}
\hline \multirow{2}{*}{ Cover Measurement } & \multirow{2}{*}{ Depth Range (m) } & \multicolumn{5}{|c|}{ Linear Regression Results } \\
\hline & & Slope (b) & $\mathbf{R}$ & Adjusted $R^{2}$ & $p$ & Sig. \\
\hline \multirow{3}{*}{ Year by year totals } & $\begin{array}{l}\text { Shallow } \\
Q_{<}<115 \mathrm{~m}\end{array}$ & 18 & 0.84 & 0.61 & 0.074 & * \\
\hline & $\begin{array}{l}\text { Moderate } \\
>>1.15 \text { to } 1.4\end{array}$ & 37 & 0.75 & 0.42 & 0.141 & * \\
\hline & $\begin{array}{l}\text { Deep } \\
\boldsymbol{v}_{>>1.4}\end{array}$ & 11 & 0.59 & 0.13 & 0.297 & ns \\
\hline \multirow{3}{*}{$\begin{array}{l}\text { Cumulative 'footprint' } \\
\text { overtime }\end{array}$} & Shallow & 37 & 0.99 & 0.98 & 0.001 & $* * *$ \\
\hline & $\begin{array}{l}\text { Moderate } \\
\square>1.15 \text { to } 1.4\end{array}$ & 95 & 0.99 & 0.98 & 0.001 & $* * *$ \\
\hline & Deep & 46 & 0.99 & 0.98 & 0.001 & $* * *$ \\
\hline
\end{tabular}

Measurement errors are compounded when calculating change from multiple classifications estimates [113]. Therefore, estimates of cumulative cover may be exaggerated. However, there are several reasons to suspect that the majority of the differences observed between the year totals and the cumulative footprint (Figure 13, Table 6) are real. Firstly, reduction in para grass cover does occur after fire, although the impact on para grass survival is variable and likely to be dependent on the severity of fire and the hydrological conditions before and after fire [114]. Secondly, periodic reductions in para grass cover might occur within the 'optimal' moderate depth habitat zone, in years when hydrological fluctuations occur that are outside the norm. In these cases, changes in local habitat conditions 
can amplify competition from coexisting native vegetation $[115,116]$. Thirdly, localized depletion of nutrients after invasion might cause periodic reductions in para grass cover-density. Individual para grass patches were sometimes ring-shaped, or were observed to move with an advancing growth front while also contracting behind this front. In other words, vigorous production by para grass may occur at an invasion front, in new areas not fully exploited of nutrients, while senescence and less vigorous growth occurs progressively in longer established areas where nutrient levels may have been depleted, locally. In support of this hypothesis, para grass productivity increases dramatically in response to increased nutrients [117].

In addition to these sites of dynamic para grass cover, more 'permanent' para grass patches were also apparent as illustrated by the mapped para grass 'persistence' score (Figure 14a). Patches that were more persistent tended to be in closer proximity to one another (Figure 14c) and persistence was highest in shallower depth-habitats, while the spread of para grass was fastest in the moderate water depth habitats (Figure 13, above). The degree to which cover density within established patches is fluctuating, while persistent patch abundance is increasing, can only be determined by longer-term sampling. The rate at which these patches form and whether these patches should be targeted in active control programs is an important management question. This could be answered experimentally by targeted field research and weed control.

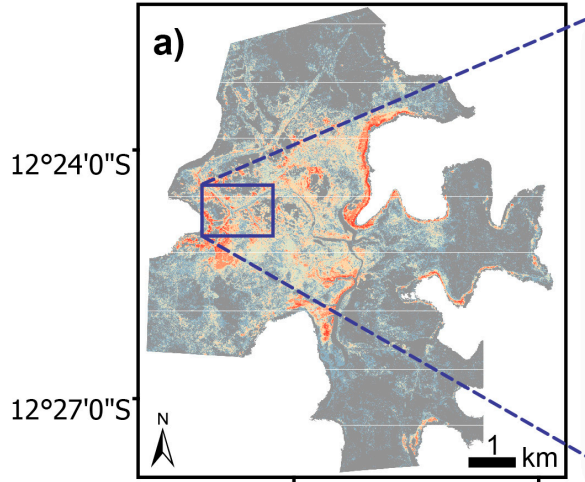

$132{ }^{\circ} 51^{\prime} 0 " \mathrm{E}$

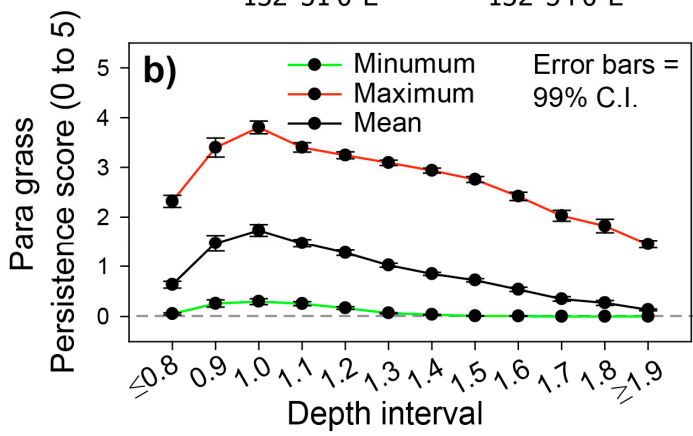

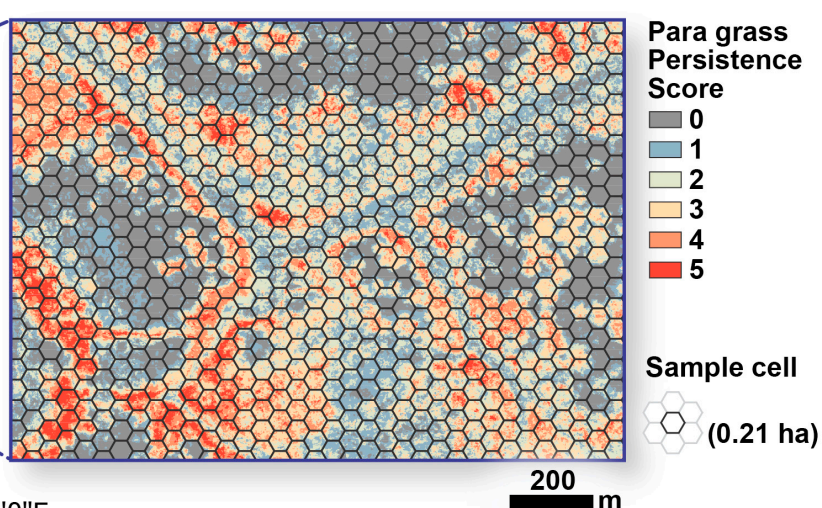

200

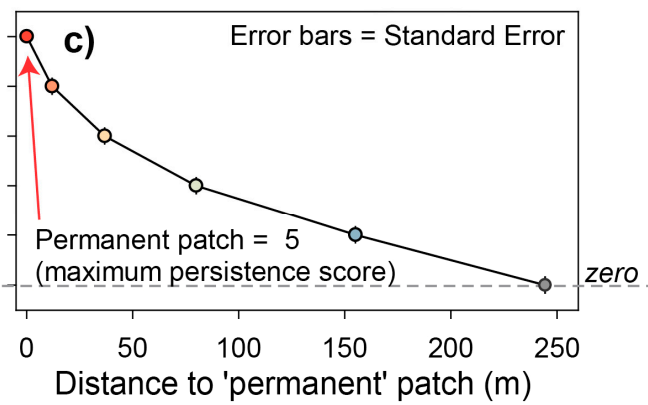

Figure 14. (a) The mapped para grass 'persistence' score calculated by the sum of the present-absent map layers ( $n=5$, from 2001 to 2010); (b) the distribution of the persistence score across the depth gradient intervals, measured by the cell-sample means; and (c) the mean distance between 'permanent' patches, less persistent patches and where zero para grass was scored over the entire map time-series.

In the absence of fire, the density of para grass cover increased across all depth categories, with the most pronounced increase occurring in the moderate and shallow depth zones (Figure 15a). The related African floodplain grass, Urochloa mosambicensis, was found to behave similarly in the absence of fire, with cover density and extent increasing and plant biodiversity decreasing continuously for 8 years [108]. 

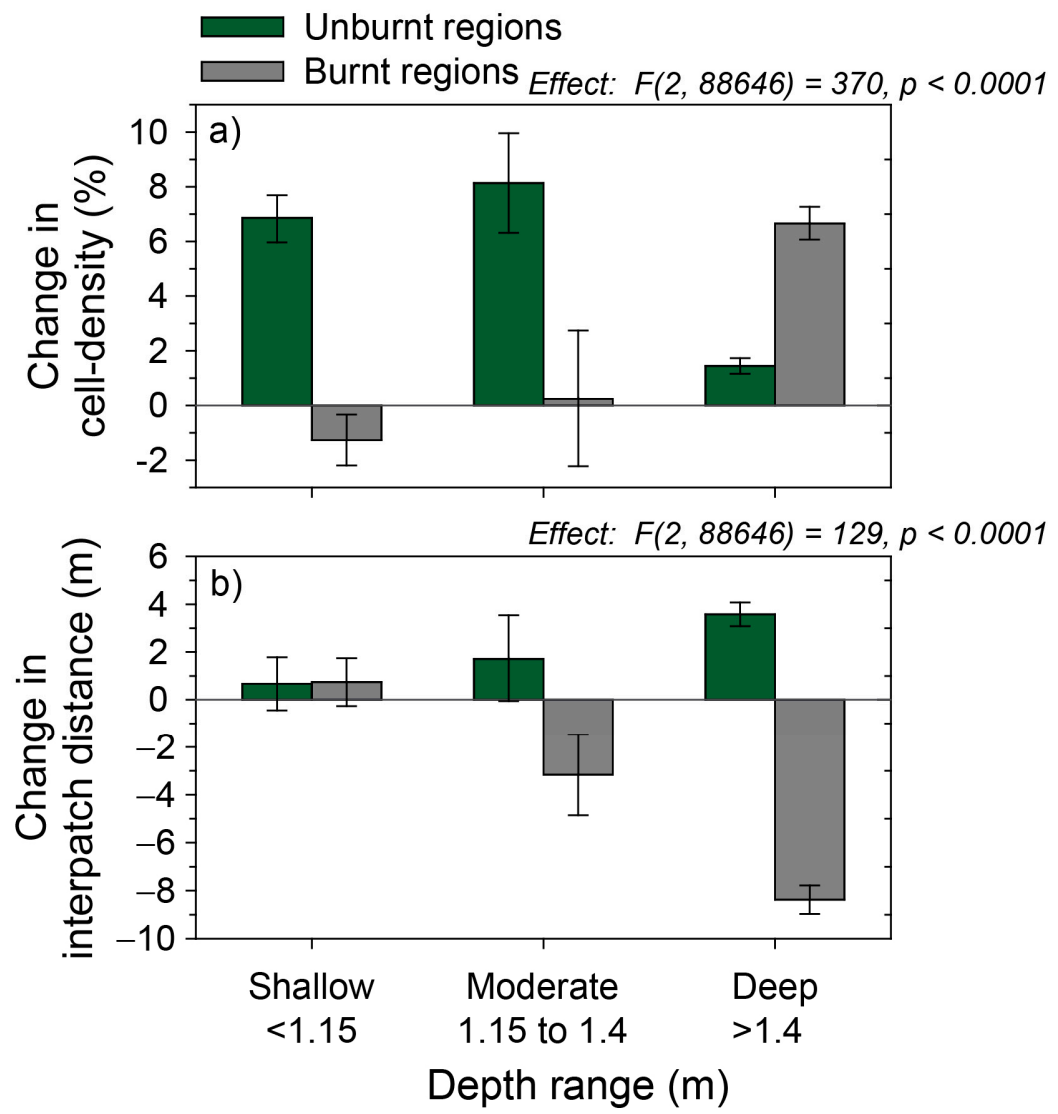

Figure 15. Results of a two-way ANOVA suggesting the interactive effects of depth regime and fire on para grass as measured by changes in: (a) Cover-density; and (b) para grass inter-patch distance. Numerical results from the ANOVA are shown in italics. Error bars are the $99 \%$ confidence interval.

The distance between para grass patches also increased in the two deeper depth habitats in the absence of fire (Figure 15b). This suggests that the spread of para grass in deeper habitats may be restricted by competitive interactions with other aquatic plants, such as perennial Hymenachne grass, that favor this habitat [51].

Conversely, fire appeared to facilitate the spread of para grass in the deep habitat $(>1.4 \mathrm{~m})$. Fire has been demonstrated to substantially reduce the abundance of native Hymenachne grassland [30,118]. Occurrences of dry season fire in the 'deep' habitat indicate that water levels were lower at the time but soil moisture remained high, providing conditions for para grass growth.

Previous findings suggest that, in general, para grass has a faster growth rate than native $H$. acutigluma $[117,119,120]$. However, these results also suggest that, in an absence of fire and in deeper water habitats, native Hymenachne may competitively exclude para grass, under these conditions. Further trials, monitoring growth under different inundation regimes of the floodplain, may be necessary in order to quantify the differences between these two grass species in different wetland habitats.

From a management perspective, the positive or negative influences of fire (and timing of fire for most effective control of para grass or establishment of native species) are likely to be context specific and be related to local hydrological regimes [54,114,121]. Our initial results suggest that, within different depth habitats, different approaches in application (or suppression) of fire may be required to assist in control of para grass. Further research into these dynamics is therefore necessary if fire, in combination with other control methods, is to be skillfully applied to manage para grass on Kakadu wetlands. 


\section{Conclusions}

Aquatic weeds remain a significant threat to the degradation of wetland systems that support economic and cultural livelihoods, ecosystem services and biodiversity conservation values, globally. This study demonstrated that satellite RS can provide a valuable spatial information framework from which to monitor vegetation condition across wetlands and over multiple scales. It also points to site-specific opportunities for targeted management actions, such as controlled burning. However, in order to manage uncertainty in RS vegetation monitoring, it is also important to develop and maintain a consistent and statistically rigorous foundation to train and validate satellite imagery.

Ideally, land management decision makers require timely and accurate information on weed distribution change. However, the delivery of consistent, high quality, information for detection and prediction of vegetation change will also require a long-term, ongoing, commitment and resourcing from bodies governing the conservation management of wetlands. As shown in Figure 16, a basic framework for coordinated effort to monitor, research and manage vegetation change, using our case study as an example (revised from [121,122]).

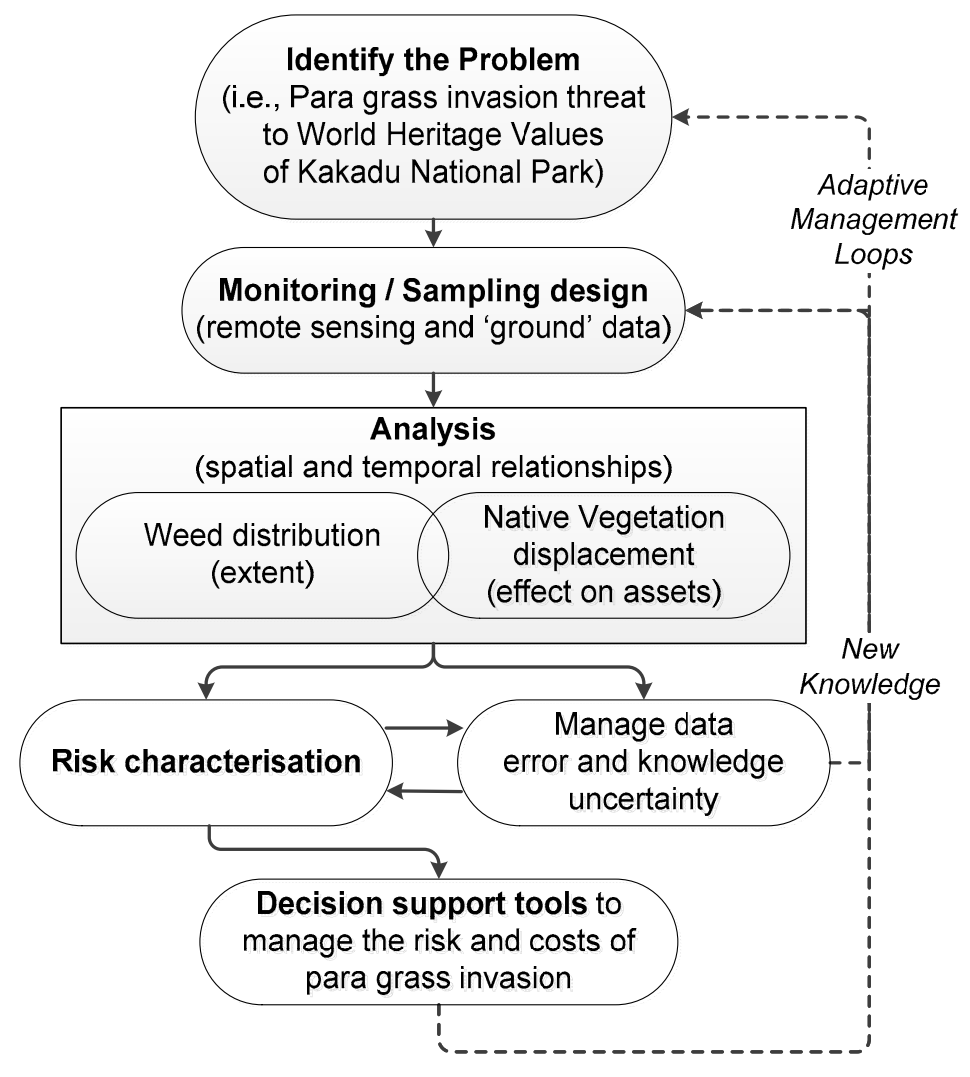

Figure 16. A conceptual basis for the strategic management of para grass invasion on wetlands of Kakadu National Park using spatially explicit monitoring, ecological risk assessment and adaptive management. Revised from (US EPA [122]] and [Boyden, et al. [123]).

As this case study and others indicate, para grass continues to expand its distribution and density on freshwater floodplains of northern Australia and elsewhere. On the Magela floodplain, some 20\% of the area previously mapped as native Oryza and Hymenachne in 1986, appear to have been displaced by dense para grass in 2006. Phases of both spread and contraction in para grass were also mapped. Despite periodic contraction of many para grass colonies, discreet patches continued to increase in size and coalesce to form larger patches. The concern is that the ongoing formation of larger, persistent, patches of para grass could lead to greater depletion of native plant seedbanks and habitat areas valuable for conservation. 
Methods to remediate depleted native grasslands could involve the selective control of weed cover. As results of this study suggest, effective strategies for para grass control are likely to benefit from better understanding of the judicious use (or exclusion) of fire within different floodplain habitats. In this context, we provide the initial spatial information required to design and coordinate future applied research on site-specific control strategies for para grass and other aquatic weeds.

Author Contributions: J.B. designed and conducted all the analyses and wrote the manuscript. P.W. was principle supervisor of the PhD student (J.B.) and contributed through advising on research objectives, paper structure and landscape ecology aspects of the work and provided expert comment on paper revisions. In order of relative contribution: K.J. and G.B. provided co-supervision of the research through discussions on the analytical approach taken and provision of technical advice on remote sensing and landscape ecology aspects of the work and provided expert comment on paper revisions.

Funding: This research was funded by an Australian Postgraduate Award. Financial support was also provided by the Australian Government and in-kind support was also through Parks Australia North; the Environmental Research Institute of the Supervising Scientist (ERISS); Charles Darwin University and Energy Resources Australia, Pty. Ltd. The APC was funded by a personal contribution from the authors as well funds available from Charles Darwin and James Cook Universities, Australia.

Acknowledgments: We thank the traditional custodians of Kakadu for their valuable knowledge and support and access to the lands on which this research was conducted. This research would also not have been possible without support provided from the Australian Government; Charles Darwin University (CDU); Parks Australia North; the Environmental Research Institute of the Supervising Scientist (ERISS); and Energy Resources Australia (ERA). Thanks also go to members of the KNP weed management team, Buck Salau and airboat pilots Freddy Hunter, Calvin Murikami, Dwayne and David Brown for assisting with fieldwork and our safe travels. Finally, I (J.B.) want to thank Peter Bayliss; three thesis examiners who provided constructive comments on PhD material that was used in this work; and three anonymous reviewers who each provided constructive feedback on earlier versions of this manuscript).

Conflicts of Interest: The authors declare no conflict of interest.

\section{References}

1. Assessment, M.E. Ecosystems and Human Well-Being: Wetlands and Water; World Resources Institute: Washington, DC, USA, 2005.

2. Hu, S.; Niu, Z.; Chen, Y.; Li, L.; Zhang, H. Global wetlands: Potential distribution, wetland loss, and status. Sci. Total Environ. 2017, 586, 319-327. [CrossRef]

3. Zedler, J.B.; Kercher, S. Causes and consequences of invasive plants in wetlands: Opportunities, opportunists, and outcomes. Crit. Rev. Plant Sci. 2004, 23, 431-452. [CrossRef]

4. Kurugundla, C.; Mathangwane, B.; Sakuringwa, S.; Katorah, G. Alien Invasive Aquatic Plant Species in Botswana: Historical Perspective and Management. Open Plant Sci. J. 2016, 9. [CrossRef]

5. Finlayson, C.; Gitay, H.; Bellio, M.; van Dam, R.; Taylor, I. Climate variability and change and other pressures on wetlands and waterbirds: Impacts and adaptation. In Waterbirds around the World: A Global Overview of the Conservation, Management and Research of the World's Waterbird Flyways; The Stationery Office: London, UK, 2006; pp. 88-97.

6. Low, T. Tropical pasture plants as weeds. Trop. Grassl. 1997, 31, 337-343.

7. Bunn, S.E.; Davies, P.M.; Kellaway, D.M.; Prosser, I.P. Influence of invasive macrophytes on channel morphology and hydrology in an open tropical lowland stream, and potential control by riparian shading. Freshw. Biol. 1998, 39, 171-178. [CrossRef]

8. Bellairs, S.M.; Wurm, P.A.S.; Kernich, B. Temperature affects the dormancy and germination of sympatric annual Oryza meridionalis and perennial O. rufipogon native Australian rices (Poaceae) and influences their emergence in introduced para grass Urochloa mutica swards. Aust. J. Bot. 2015, 63, 687-695. [CrossRef]

9. Wurm, P. Suppression of germination and establishment of native annual rice by introduced para grass on an Australian monsoonal floodplain. Plant Prot. Q. 2007, 22, 106.

10. Barrow, P. Fire management and research in Kakadu. In Supervising Scientist Report 148: A Compendium of Information for Managing and Monitoring Wetlands in Tropical Australia; Finlayson, C.M., Spiers, A.G., Eds.; Supervising Scientist: Canberra, Australia, 1999; pp. 198-206. 
11. Douglas, M.M.; O'Connor, R.A. Weed invasion changes fuel characteristics: Para grass (Urochloa mutica (Forssk.) T.Q. Nguyen) on a tropical floodplain. Ecol. Manag. Restor. 2004, 5, 143-145. [CrossRef]

12. Finlayson, C.M. Plant ecology of Australia's tropical floodplain wetlands: A review. Ann. Bot. 2005, 96, 541-555. [CrossRef]

13. Finlayson, C.M.; Storrs, M.J.; Lindner, G. Degradation and rehabilitation of wetlands in the Alligator Rivers Region of northern Australia. Wetl. Ecol. Manag. 1997, 5, 19-36. [CrossRef]

14. Setterfield, S.A.; Rossiter-Rachor, N.A.; Douglas, M.M.; Wainger, L.; Petty, A.M.; Barrow, P.; Shepherd, I.J.; Ferdinands, K.B. Adding fuel to the fire: The impacts of non-native grass invasion on fire management at a regional scale. PLoS ONE 2013, 8, e59144. [CrossRef] [PubMed]

15. Finlayson, C.M.; Lowry, J.B.; Bellio, M.G.; Nou, S.; Pidgeon, R.; Walden, D.; Humphrey, C.; Fox, G. Biodiversity of wetlands of the Kakadu Region, northern Australia. Aquat. Sci. 2006, 68, 374-399. [CrossRef]

16. Ferdinands, K.B.; Beggs, K.; Whitehead, P.J. Biodiversity and invasive grass species: Multiple-use or monoculture? Wildl. Res. 2005, 32, 447-457. [CrossRef]

17. AVH. Australian Virtual Herbarium Occurrence Records: Urochloa Mutica. Available online: https: //avh.chah.org.au/ (accessed on 28 August 2019).

18. Ramsar. Convention on Wetlands of International Importance especially as Waterfowl Habitat. Ramsar (Iran). UN Treaty Series No. 14583. As amended in 1982 and 1987. Available online: http://www.ramsar.org/ (accessed on 28 August 2019).

19. Knerr, N. Grassland Community Dynamics of a Freshwater Tropical Floodplain: Invasion of Brachiaria Mutica (Para Grass) on The Magela Floodplain, Kakadu National Park. Bachelor's Thesis, University of New England, Armidale, NSW, Australia, 1996.

20. Boyden, J.M.; Joyce, K.E.; Boggs, G.; Wurm, P. Object-based mapping of native vegetation and para grass (Urochloa mutica) on a monsoonal wetland of Kakadu NP using a Landsat 5 TM Dry-season time series. J. Spat. Sci. 2013, 58, 53-77. [CrossRef]

21. Walden, D.; Boyden, J.; Bayliss, P.; Ferdinands, K. A preliminary ecological risk assessment of the major weeds on the Magela Creek floodplain, Kakadu National Park; Supervising Scientist Report 194; Supervising Scientist (Aust. Govt.): Darwin, NT, Australia, 2012; ISBN 978-1-921069-19-2.

22. Whitehead, P.J.; Dawson, T. Let them eat grass. Nat. Aust. (Autumn) 2000, 45-55.

23. Whitehead, P.J.; Wilson, B.A.; Bowman, D.M.J.S. Conservation status of coastal wetlands of the Northern Territory of Australia: The Mary River floodplain. Biol. Conserv. 1990, 52, 85-111. [CrossRef]

24. Stein, J.C.; Yu, Y.; Copetti, D.; Zwickl, D.J.; Zhang, L.; Zhang, C.; Chougule, K.; Gao, D.; Iwata, A.; Goicoechea, J.L.; et al. Genomes of 13 domesticated and wild rice relatives highlight genetic conservation, turnover and innovation across the genus Oryza. Nat. Genet. 2018, 50, 285-296. [CrossRef]

25. Hoang, T.M.L.; Tran, T.N.; Nguyen, T.K.T.; Williams, B.; Wurm, P.; Bellairs, S.; Mundree, S. Improvement of Salinity Stress Tolerance in Rice: Challenges and Opportunities. Agronomy 2016, 6, 54. [CrossRef]

26. Frith, H.; Davies, S. Ecology of the Magpie Goose, Anseranas semipalmata Latham (Anatidae). CSIRO Wildl. Res. 1961, 6, 91-141. [CrossRef]

27. Whitehead, P.J.; Saalfeld, K. Nesting phenology of magpie geese (Anseranas semipalmata) in monsoonal northern Australia: Responses to antecedent rainfall. J. Zool. 2000, 251, 495-508. [CrossRef]

28. Redhead, T.D. On the demography of Rattus sordidus colletti in monsoonal Australia. Aust. J. Ecol. 1979, 4, 115-136. [CrossRef]

29. Wurm, P. A surplus of seeds: High rates of post-dispersal seed predation in a flooded grassland in monsoonal Australia. Aust. J. Ecol. 1998, 23, 385-392. [CrossRef]

30. McGregor, S.; Lawson, V.; Christophersen, P.; Kennett, R.; Boyden, J.M.; Bayliss, P.; Liedloff, A.; McKaige, B.; Andersen, A.N. Indigenous wetland burning: Conserving natural and cultural resources in Australia's World Heritage-listed Kakadu National Park. Hum. Ecol. 2011, 32, 721-729. [CrossRef]

31. Ligtermoet, E. Maintaining customary harvesting of freshwater resources: Sustainable Indigenous livelihoods in the floodplains of northern Australia. Rev. Fish Biol. Fish. 2016, 26, 649-678. [CrossRef]

32. Vilà, M.; Ibáñez, I. Plant invasions in the landscape. Landsc. Ecol. 2011, 26, 461-472. [CrossRef]

33. Catford, J.A.; Vesk, P.A.; White, M.D.; Wintle, B.A. Hotspots of plant invasion predicted by propagule pressure and ecosystem characteristics. Divers. Distrib. 2011, 17, 1099-1110. [CrossRef] 
34. Allen, C.; Johnson, A.; Parris, L. A Framework for Spatial Risk Assessments: Potential Impacts of Nonindigenous Invasive Species on Native Species. Ecol. Soc. 2006, 11, 39. [CrossRef]

35. Hobbs, R.; Humphries, S. An integrated approach to the ecology and management of plant invasions. Conserv. Biol. 1995, 9, 761-770. [CrossRef]

36. With, K.A. The landscape ecology of invasive spread. Conserv. Biol. 2002, 16, 1192-1203. [CrossRef]

37. Rodgers, L.; Pernas, T.; Redwine, J.; Shamblin, B.; Bruscia, S. Multiscale Invasive Plant Monitoring: Experiences from the Greater Everglades Restoration Area. Weed Technol. 2018, 32, 11-19. [CrossRef]

38. Levick, S.; Rogers, K. Context-dependent vegetation dynamics in an African savanna. Landsc. Ecol. 2011, 26, 515-528. [CrossRef]

39. Randall, J.M.; Cole, D.; McCool, S.; Borrie, W. Improving management of nonnative invasive plants in wilderness and other natural areas. In Proceedings of the Wilderness Science in a Time of Change Conference-Volume 5: Wilderness Ecosystems, Threats, and Management, Missoula, MT, USA, 23-27 May 1999; U.S. Department of Agriculture, Forest Service, Rocky Mountain Research Station: Missoula, MT, USA, 2000; pp. 64-73.

40. Harvey, K.R.; Hill, G.J.E. Vegetation mapping of a tropical freshwater swamp in the Northern Territory, Australia: A comparison of aerial photography, Landsat TM and SPOT satellite imagery. Int. J. Remote Sens. 2001, 22, 2911-2925. [CrossRef]

41. D'Antonio, C.M.; Jackson, N.E.; Horvitz, C.C.; Hedberg, R. Invasive plants in wildland ecosystems: Merging the study of invasion processes with management needs. Front. Ecol. Environ. 2004, 2, 513-521. [CrossRef]

42. Finlayson, C.M.; Rea, N. Reasons for the loss and degradation of Australian wetlands. Wetl. Ecol. Manag. 1999, 7, 1-11. [CrossRef]

43. MacKay, H.; Finlayson, C.M.; Fernandez-Prieto, D.; Davidson, N.; Pritchard, D.; Rebelo, L.-M. The role of Earth Observation (EO) technologies in supporting implementation of the Ramsar Convention on Wetlands. J. Environ. Manag. 2009, 90, 2234-2242. [CrossRef] [PubMed]

44. Sanderson, N.; Koontz, D.; Morley, A. The Ecology of the Vegetation of the Magela Creek Floodplain: Upper Section from Oenpelli Road Crossing to Nankeen Billabong. In Proceedings of the Scientific Workshop, Environmental Protection in the Alligator Rivers Region, Jabiru, Australia, 17-20 May 1983; pp. 17-20.

45. Casanova, M.T.; Brock, M.A. How do depth, duration and frequency of flooding influence the establishment of wetland plant communities? Plant Ecol. 1983, 147, 237-250. [CrossRef]

46. Finlayson, C.M. Vegetation changes and biomass on an Australian monsoonal floodplain. In Wetlands and Ecotones: Studies on Land-Water Interactions; Gopal, B., Hillbreicht-Ilkowska, A., Wetzel, R., Eds.; National Institute of Ecology and International Scientific Publications: New Delhi, Germany, 1993; pp. 157-172.

47. Middleton, B. Succession and herbivory in monsoonal wetlands. Wetl. Ecol. Manag. 1999, 6, $189-202$. [CrossRef]

48. Ngari, A.N.; Kinyamario, J.I.; Ntiba, M.J.; Mavuti, K.M. Factors affecting abundance and distribution of submerged and floating macrophytes in Lake Naivasha, Kenya. Afr. J. Ecol. 2009, 47, 32-39. [CrossRef]

49. Peters, J. Ecohydrology of Wetlands: Monitoring and Modelling Interactions Between Groundwater, Soil and Vegetation. Ph.D. Thesis, Faculty of Bioscience Engineering, Ghent University, Ghent, Belgium, 2008.

50. Whitehead, P.J.; Russell-Smith, J.; Woinarski, J.C.Z. Fire, landscape heterogeneity and wildlife management in Australia's tropical savannas: Introduction and overview. Wildl. Res. 2008, 32, 369-375. [CrossRef]

51. Boyden, J.; Wurm, P.; Joyce, K.E.; Boggs, G. A spatial vulnerability assessment of monsoonal wetland habitats to para grass invasion in Kakadu National Park, northern Australia. Int. J. Appl. Earth Obs. Geoinf. 2018, 71, 43-55. [CrossRef]

52. Ward, D.P.; Petty, A.M.; Setterfield, S.A.; Douglas, M.M.; Ferdinands, K.B.; Hamilton, S.K.; Phinn, S.R. Floodplain inundation and vegetation dynamics in the Alligator Rivers region (Kakadu) of northern Australia assessed using optical and radar remote sensing. Remote Sens. Environ. 2014, 147, 43-55. [CrossRef]

53. Williams, P.R.; Collins, E.M.; Grice, A.C.; Mike Nicholas, D.; Perry, J.J. The role of fire in germinating wild rice (Oryza meridionalis), an annual grass of northern Australian wetlands threatened by exotic grass invasion. Ecol. Manag. Restor. 2011, 12, 74-76. [CrossRef]

54. Grice, A.; Nicholas, M. Using fire to restore Australian wetlands from invasive grasses, Rural Industries Research and Development Corporation. Aust. Gov. 2011, 11. 
55. Hobbs, R.; Huenneke, L. Disturbance, diversity, and invasion: Implications for conservation (review). Conserv. Biol. 1992, 6, 324-337. [CrossRef]

56. Wallace, J.; Caccetta, P.A.; Kiiver, H.T. Recent developments in analysis of spatial and temporal data for landscape qualities and monitoring. Austral Ecol. 2004, 29, 100-107. [CrossRef]

57. Dronova, I.; Knox, S.H.; Taddeo, S.; Hemes, K.S.; Valach, A.C.; Oikawa, P.; Baldocchi, D.D. The potential of remotely sensed phenology as indicator of structure and function in wetland ecosystems (356823). In Proceedings of the 2018 AGU Fall Meeting, Washington, DC, USA, 10-14 December 2018.

58. Dronova, I.; Spotswood, E.N.; Suding, K.N. Opportunities and Constraints in Characterizing Landscape Distribution of an Invasive Grass from Very High Resolution Multi-Spectral Imagery. Front. Plant Sci. 2017, 8, 890. [CrossRef] [PubMed]

59. Dronova, I.; Gong, P.; Wang, L.; Zhong, L. Mapping dynamic cover types in a large seasonally flooded wetland using extended principal component analysis and object-based classification. Remote Sens. Environ. 2015, 158, 193-206. [CrossRef]

60. Boyden, J.M.; Walden, D.; Bartolo, R.; Bayliss, P. Utility of VHR remote sensing data for landscape scale assessment of the environmental weed, para grass [Urochloa mutica, (FORSSK), Nguyen], on a tropical floodplain. In Proceedings of the 28th Asian Conference on Remote Sensing, Kuala, Lumpur, 12-16 November 2008.

61. Becker, B.L.; Lusch, D.P.; Qi, J. A classification-based assessment of the optimal spectral and spatial resolutions for Great Lakes coastal wetland imagery. Remote Sens. Environ. 2007, 108, 111-120. [CrossRef]

62. De Roeck, E.; Verhoest, N.; Miya, M.; Lievens, H.; Batelaan, O.; Thomas, A.; Brendonck, L. Remote sensing and wetland ecology: A South African case study. Sensors 2008, 8, 3542-3556. [CrossRef]

63. Dronova, I.; Gong, P.; Wang, L. Object-based analysis and change detection of major wetland cover types and their classification uncertainty during the low water period at Poyang Lake, China. Remote Sens. Environ. 2011, 115, 3220-3236. [CrossRef]

64. Johnston, R.; Barson, M. Remote sensing of Australian wetlands: An evaluation of Landsat TM data for inventory and classification. Aust. J. Mar. Freshw. Res. 1993, 44, 235-252. [CrossRef]

65. Klemas, V. Remote sensing of wetlands: Case studies comparing practical techniques. J. Coast. Res. 2011, 27, 418-427.

66. Laba, M.; Downs, R.; Smith, S.; Welsh, S.; Neider, C.; White, S.; Richmond, M.; Philpot, W.; Baveye, P. Mapping invasive wetland plants in the Hudson River National Estuarine Research Reserve using QuickBird satellite imagery. Remote Sens. Environ. 2008, 112, 286-300. [CrossRef]

67. Lunetta, R.; Balogh, M. Application of multi-temporal Landsat 5 TM imagery for wetland Identification. Photogramm. Eng. Remote Sens. 1999, 65, 1303-1310.

68. Olmanson, L.G.; Bauer, M.E.; Brezonik, P.L. Aquatic vegetation surveys using high-resolution IKONOS imagery. In Proceedings of the 15th William T. Pecora Memorial Remote Sensing Symposium; Unpaginated CD ROM: Denver, CO, USA, 2002; p. 5.

69. Ozesmi, S.L.; Bauer, M.E. Satellite remote sensing of wetlands. Wetl. Ecol. Manag. 2002, 10, $381-402$. [CrossRef]

70. Ward, D.P.; Hamilton, S.K.; Jardine, T.D.; Pettit, N.E.; Tews, E.K.; Olley, J.M.; Bunn, S.E. Assessing the seasonal dynamics of inundation, turbidity, and aquatic vegetation in the Australian wet-dry tropics using optical remote sensing. Ecohydrology 2012, 6, 312-323. [CrossRef]

71. Gillanders, S.N.; Coops, N.C.; Wulder, M.A.; Gergel, S.E.; Nelson, T. Multitemporal remote sensing of landscape dynamics and pattern change: Describing natural and anthropogenic trends. Prog. Phys. Geography 2008, 32, 503-528. [CrossRef]

72. Shaw, D. Translation of remote sensing data into weed management decisions. Weed Sci. 2005, 53, $264-273$. [CrossRef]

73. Kennedy, R.E.; Townsend, P.A.; Gross, J.E.; Cohen, W.B.; Bolstad, P.; Wang, Y.Q.; Adams, P. Remote sensing change detection tools for natural resource managers: Understanding concepts and tradeoffs in the design of landscape monitoring projects. Remote Sens. Environ. 2009, 113, 1382-1396. [CrossRef]

74. Abeysinghe, T.; Simic Milas, A.; Arend, K.; Hohman, B.; Reil, P.; Gregory, A.; Vázquez-Ortega, A. Mapping Invasive Phragmites australis in the Old Woman Creek Estuary Using UAV Remote Sensing and Machine Learning Classifiers. Remote Sens. 2019, 11, 1380. [CrossRef] 
75. Whiteside, T.G.; Bartolo, R.E. Mapping Aquatic Vegetation in a Tropical Wetland Using High Spatial Resolution Multispectral Satellite Imagery. Remote Sens. 2015, 7, 11664-11694. [CrossRef]

76. Gray, P.; Ridge, J.; Poulin, S.; Seymour, A.; Schwantes, A.; Swenson, J.; Johnston, D. Integrating drone imagery into high resolution satellite remote sensing assessments of estuarine environments. Remote Sens. 2018, 10, 1257. [CrossRef]

77. Shao, G.; Wu, J. On the accuracy of landscape pattern analysis using remote sensing data. Landsc. Ecol. 2008, 23, 505-511. [CrossRef]

78. Lunetta, R. Chapter 1: Applications, project formulation, and analytical approach. In Remote Sensing Change Detection: Environmental Monitoring Methods and Applications; Lunetta, R., Elvidge, C., Eds.; Ann Arbor Press: Michigan, MI, USA, 1998; pp. 1-20.

79. Coppin, P.; Jonkheere, I.; Nackaerts, K.; Muys, B. Digital change detection methods in ecosystem monitoring: A review. Int. J. Remote Sens. 2004, 25, 1565-1596. [CrossRef]

80. Salau, R. Para Grass in Kakadu National Park: Unpublished Paper Presented to Natural Resource Management Canberra; Australian Nature Conservation Agency: Canberra, Australia, 1995.

81. Wesley-Smith, R. Para grass in the Northern Territory: Parentage and propagation. Trop. Grassl. 1973, 7, 249-250.

82. Petty, A.M.; Werner, P.A.; Lehmann, C.E.R.; Riley, J.E.; Banfai, D.S.; Elliott, L.P. Savanna responses to feral buffalo in Kakadu National Park, Australia. Ecol. Monogr. 2007, 77, 441-463. [CrossRef]

83. Finlayson, C.M.; Bailey, B.J.; Cowie, I.D. Macrophyte vegetation of the Magela Creek flood plain, Alligator Rivers Region, Northern Territory. In Research Report 5; Supervising Scientist for the Alligator Rivers Region: Canberra, Australia, 1989.

84. Pfitzner, K. IKONOS and ASTER Imagery: Ranger Mine and the Magela Floodplain Area; Supervising Scientist: Darwin, Australia, 2003.

85. Excelis. ENVI User Manual; ITT Visual Information Solutions: Boulder CO, USA, 2010.

86. Trimble. Reference Book: eCognition ${ }^{\circledR}$ Developer 8.64.1; Trimble Germany GmbH: Trappentreustr. 1, D-80339 München, Germany, 2011.

87. ESRI. ArcMap Version 9.3.1; Environmental Systems Research Institute, Inc. (ESRI): Redlands, CA, USA, 2006.

88. Boyden, J. Remote Sensing Applications: Understanding the Landscape Ecology of Invasive Para Grass (urochloa mutica) on Monsoonal Wetlands, Kakadu National Park, Australia. Ph.D. Thesis, Charles Darwin University, Darwin, Australia, 2016.

89. Baker, C.; Lawrence, R.; Montagne, C.; Patten, D. Change detection of wetland ecosystems using Landsat imagery and change vector analysis. Wetlands 2007, 27, 610-619. [CrossRef]

90. Lawrence, R.; Bunn, A.; Powell, S.; Zambon, M. Classification of remotely sensed imagery using stochastic gradient boosting as a refinement of classification tree analysis. Remote Sens. Environ. 2004, 90, 331-336. [CrossRef]

91. McIver, D.K.; Friedl, M.A. Using prior probabilities in decision-tree classification of remotely sensed data. Remote Sens. Environ. 2002, 81, 253-261. [CrossRef]

92. Zhu, X. Wetland mapping using remote sensing imagery and ModelMap. In Proceedings of the Surveying and Spatial Science Biennial Conference, Wellington, New Zealand, 21-25 November 2011.

93. Friedman, J. Stochastic gradient boosting. Comput. Stat. Data Anal. 2002, 38, 367-378. [CrossRef]

94. Friedman, J Greedy function approximation: A gradient boosting machine. Ann. Stat. 2001, 29, 1189-1232. [CrossRef]

95. Friedman, J.; Hastie, T.; Tibshirani, R. Special invited paper. Additive logistic regression: A statistical view of boosting. Ann. Stat. 2000, 28, 337-374. [CrossRef]

96. Kim, H.-C.; Pang, S.; Je, H.-M.; Kim, D.; Bang, S.Y. Constructing support vector machine ensemble. Pattern Recognit. 2003, 36, 2757-2767. [CrossRef]

97. Elith, J.; Leathwick, J.R.; Hastie, T. A working guide to boosted regression trees. J. Anim. Ecol. 2008, 77, 802-813. [CrossRef] [PubMed]

98. Andrew, M.E.; Ustin, S.L. The role of environmental context in mapping invasive plants with hyperspectral image data. Remote Sens. Environ. 2008, 112, 4301-4317. [CrossRef] 
99. Lu, D.; Weng, Q. A survey of image classification methods and techniques for improving classification performance. Int. J. Remote Sens. 2007, 28, 823-870. [CrossRef]

100. StatSoft-Inc. Statistica 64 ver. 11 (data Analysis Software System). Available online: http://www.statsoft.com (accessed on 28 August 2019).

101. Lewin-Koh, N. Hexagonal Binning: An overview. 14 May 2019. Available online: http://cran.r-project.org/ web/packages/hexbin/vignettes/hexagon_binning.pdf (accessed on 28 August 2019).

102. Carr, D.B.; Olsen, A.R.; White, D. Hexagon mosaic maps for display of univariate and bivariate geographical data. Cartogr. Geogr. Inf. Sci. 1992, 19, 228-236. [CrossRef]

103. Anselin, L. Local indicators of spatial association-LISA. Geogr. Anal. 1995, 27, 93-115. [CrossRef]

104. Ferdinands, K.B. Assessing the Threat Posed by an Invasive African Grass Urochloa Mutica (Forssk) Nguyen to Biodiversity Conservation in the Mary River Wetlands, Northern Territory. Ph.D. Thesis, Charles Darwin University, Darwin, Australia, 2007.

105. Douglas, M.M.; O'Connor, R.A. Effects of the exotic macrophyte, para grass (Urochloa mutica), on benthic and epiphytic macroinvertebrates of a tropical floodplain. Freshw. Biol. 2003, 48, 962-971. [CrossRef]

106. Douglas, M.M.; Bunn, S.E.; Pidgeon, R.J.; Davies, P.M.; Barrow, P.; O'Connor, R.A.; Winning, M. Weed Management and the Biodiversity and Ecological Processes of Tropical Wetlands; Final Report; National Wetlands, R.\& D Program, Environment Australia \& Land and Water Australia: Canberra, ACT, Australia, 2001.

107. Setterfield, S.A.; Clifton, P.J.; Hutley, L.B.; Rossiter-Rachor, N.A.; Douglas, M.M. Exotic grass invasion alters microsite conditions limiting woody recruitment potential in an Australian savanna. Sci. Rep. 2018, 8, 6628. [CrossRef]

108. Heinl, M.; Sliva, J.; Murray-Hudson, M.; Tacheba, B. Post-fire succession on savanna habitats in the Okavango Delta wetland, Botswana. J. Trop. Ecol. 2007, 23, 705-713. [CrossRef]

109. Lechner, A.M.; Stein, A.; Jones, S.D.; Ferwerda, J.G. Remote sensing of small and linear features: Quantifying the effects of patch size and length, grid position and detectability on land cover mapping. Remote Sens. Environ. 2009, 113, 2194-2204. [CrossRef]

110. Johnston, C.A.; Bridgham, S.D.; Schubauer-Berigan, J.P. Nutrient dynamics in relation to geomorphology of riverine wetlands research funded by the USDA national research initiative competitive grants program (92-37102-7406). Contribution No. 240 of the center for water and the environment. Soil Sci. Soc. Am. J. 2001, 65, 557-577. [CrossRef]

111. Chaudhari, S.; Sellers, B.A.; Rockwood, S.V.; Ferrell, J.A.; MacDonald, G.E.; Kenworthy, K.E. Nonchemical methods for para grass (Urochloa mutica) control. Invasive Plant Sci. Manag. 2012, 5, 20-26. [CrossRef]

112. BoM. Climate statistics for Australian Locations: Monthy climate Statistics for Oenpelli and East Alligator Ranger Stations, Northern Territory, Australia (Weaterh Station Numbers 14042, 14293). Available online: http://www.bom.gov.au/climate/averages/tables/cw_014042_All.shtml (accessed on 25 June 2013).

113. Lunetta, R.; Iiames, J.; Knight, J.; Congalton, R.; Mace, T. An assessment of reference data variability using a 'virtual field reference database'. Photogramm. Eng. Remote Sens. 2001, 63, 707-715.

114. Stone, K.R. Urochloa Mutica. In Fire Effects Information System; U.S. Department of Agriculture, Forest Service, Rocky Mountain Research Station, Fire Sciences Laboratory (Producer): Lakewood, CO, USA, 2010.

115. Chesson, P. Mechanisms of maintenance of species diversity. Annu. Rev. Ecol. Syst. 2000, 31, $343-366$. [CrossRef]

116. Daehler, C. Performance comparisons of co-occurring native and alien invasive plants: Implications for conservation and restoration. Annu. Rev. Ecol. Evol. Syst. 2003, 34, 183-211. [CrossRef]

117. Chadhokar, P. Effective rate and frequency of nitrogen applcations on dry matter yield and nitrogen content of para grass (Brachiaria mutica). Trop. Grassl. 1978, 12, 127-132.

118. Whitehead, P.J.; McGuffog, T. Fire and vegetation pattern in tropical floodplain grassland: A description from the Mary River and its implications for wetland management. In Proceedings of the Australian Bushfire Conference, Plaza Hotel, Darwin, NT, Australia, 8-10 July 1997; pp. 115-121.

119. Saxena, A.K.; Rana, B.S.; Rao, O.P.; Singh, B.P. Seasonal variation in biomass and primary productivity of para grass (Brachiaria mutica) under a mixed tree stand and in an adjacent open area in northern India. Agrofor. Syst. 1996, 33, 75-85. [CrossRef]

120. Finlayson, C.M. Production and major nutrient composition of three grass species on the Magela floodplain, Northern Territory, Australia. Aquat. Bot. 1991, 41, 263-280. [CrossRef] 
121. Grice, A.; Perry, J.; Nicholas, D.; Williams, P. Managing complexity: The example of invasive wetland forage grasses. In 16th Australian Weeds Conference Proceedings: Weed Management 2008 Hot Topics in the Tropics; van Klinken, R., Osten, V., Panetta, P., Scanlan, J., Eds.; Queensland Weeds Society: Queensland, Australia, 2008; pp. 27-29.

122. US EPA. Guidelines for ecological risk assessment. In Risk Assessment Forum; Environmental Protection Agency: Washington, DC, USA, 1998.

123. Boyden, J.M.; Walden, D.; Bayliss, P.; Saalfeld, K. A GIS Compendium for Landscape-Scale Risk Assessment of the Magela Creek Floodplain and Broader Alligator Rivers Region, NT; Supervising Scientist: Darwin NT, Australia, 2008.

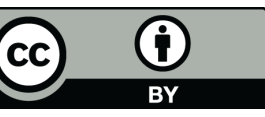

(C) 2019 by the authors. Licensee MDPI, Basel, Switzerland. This article is an open access article distributed under the terms and conditions of the Creative Commons Attribution (CC BY) license (http://creativecommons.org/licenses/by/4.0/). 